\title{
Valnoctamide Inhibits Cytomegalovirus Infection in Developing Brain and Attenuates Neurobehavioral Dysfunctions and Brain Abnormalities
}

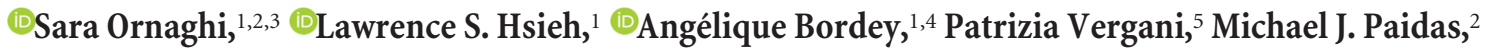 \\ and Anthony N. van den Pol ${ }^{1}$ \\ ${ }^{1}$ Department of Neurosurgery, and ${ }^{2}$ Yale Women and Children's Center for Blood Disorders and Preeclampsia Advancement, Department of Obstetrics, \\ Gynecology, and Reproductive Sciences, Yale University School of Medicine, New Haven, Connecticut, 06520, ${ }^{3}$ Ph.D. Program in Neuroscience, School of \\ Medicine and Surgery, University of Milan-Bicocca, Monza 20900, Italy, ${ }^{4}$ Department of Neurosurgery, Xiangya Hospital, Central South University, Changsha \\ 410008, People's Republic of China, and 5Department of Obstetrics and Gynecology, Foundation MBBM, San Gerardo Hospital, Monza 20900, Italy
}

Cytomegalovirus (CMV) is the most common infectious cause of brain defects and neurological dysfunction in developing human babies. Due to the teratogenicity and toxicity of available CMV antiviral agents, treatment options during early development are markedly limited. Valnoctamide (VCD), a neuroactive mood stabilizer with no known teratogenic activity, was recently demonstrated to have anti-CMV potential. However, it is not known whether this can be translated into an efficacious therapeutic effect to improve CMVinduced adverse neurological outcomes. Using multiple models of CMV infection in the developing mouse brain, we show that subcutaneous low-dose VCD suppresses CMV by reducing the level of virus available for entry into the brain and by acting directly within the brain to block virus replication and dispersal. VCD during the first 3 weeks of life restored timely acquisition of neurological milestones in neonatal male and female mice and rescued long-term motor and behavioral outcomes in juvenile male mice. CMV-mediated brain defects, including decreased brain size, cerebellar hypoplasia, and neuronal loss, were substantially attenuated by VCD. No adverse side effects on neurodevelopment of uninfected control mice receiving VCD were detected. Treatment of CMV-infected human fetal astrocytes with VCD reduced both viral infectivity and replication by blocking viral particle attachment to the cell, a mechanism that differs from available anti-CMV drugs. These data suggest that VCD during critical periods of neurodevelopment can effectively suppress CMV replication in the brain and safely improve both immediate and long-term neurological outcomes.

Key words: brain; cytomegalovirus; development; dysfunction; infection

Significance Statement

Cytomegalovirus (CMV) can irreversibly damage the developing brain. No anti-CMV drugs are available for use during fetal development, and treatment during the neonatal period has substantial limitations. We studied the anti-CMV actions of valnoctamide (VCD), a psychiatric sedative that appears to lack teratogenicity and toxicity, in the newborn mouse brain, a developmental period that parallels that of an early second-trimester human fetus. In infected mice, subcutaneous VCD reaches the brain and suppresses viral replication within the CNS, rescuing the animals from CMV-induced brain defects and neurological problems. Treatment of uninfected control animals exerts no detectable adverse effects. VCD also blocks CMV replication in human fetal brain cells.

\section{Introduction}

Cytomegalovirus (CMV) infection of the developing brain can cause a number of brain defects, including microcephaly, cortical

Received April 11, 2017; revised May 25, 2017; accepted May 31, 2017.

Author contributions:S.O. and A.N.v.d.P. designed research; S.O. and L.S.H. performed research; A.B., P.V., M.J.P., and A.N.v.d.P. contributed unpublished reagents/analytic tools; S.0. analyzed data; S.O. and A.N.v.d.P. wrote the paper.

This work was supported by funds from rEVO Biologics (M.J.P.) and National Institutes of Health Grants R01CA188359, CA-175577, CA-161048, and DK-103176 (A.N.v.d.P.). We thank John N. Davis for technical help and insightful discussions on motor and behavioral assays in adolescent mice, and Yang Yang for technical help in fluorescent staining. thinning, and cerebellar hypoplasia (Gandhi and Khanna, 2004; Mocarski et al., 2007; Cheeran et al., 2009; Tsutsui, 2009). In the United States, $\sim 30,000$ children receive diagnoses of CMV infection every year, and lifelong neurological problems, including cerebral palsy, seizures, motor impairment, intellectual disabil-

Correspondence should be addressed to Anthony N. van den Pol, Department of Neurosurgery, Yale University School of Medicine, 333 Cedar Street, New Haven, CT 06520. E-mail: anthony.vandenpol@yale.edu. D0I:10.1523/JNEUROSCI.0970-17.2017

Copyright $\odot 2017$ the authors $\quad 0270-6474 / 17 / 376877-17 \$ 15.00 / 0$ 
ity, visual deficits, and deafness, will develop in one-fifth of these children. This makes CMV the most common severely disabling perinatal infectious agent (Kenneson and Cannon, 2007; James and Kimberlin, 2016). A link between perinatal CMV infection and autism spectrum disorder (ASD) in children and adolescents has also been proposed (Stubbs et al., 1984; Yamashita et al., 2003; Sakamoto et al., 2015; Garofoli et al., 2017). Another virus that has recently raised considerable concern, and that can evoke parallel dysfunction in the developing brain, is Zika virus; importantly, in the United States neurological dysfunction due to CMV infections is $>100$-fold more prevalent than that from Zika virus (Butler, 2016). CMV evokes more brain dysfunction than more widely known diseases, including spina bifida, fetal alcohol syndrome, or Down's syndrome (Cannon and Davis, 2005).

CMV can also generate problems in the CNS of adults with a compromised immune system, including transplant recipients and AIDS patients, who are at high risk for the development of potentially life-threatening CNS complications (Mocarski et al., 2007; Mercorelli et al., 2011). A key reason that CMV is particularly damaging to the developing brain relates to the reduced efficacy of the immature innate and systemic immune response to CMV in the immature CNS (van den Pol et al., 2002, 2007; Reuter et al., 2004).

Although drugs approved to treat CMV show some efficacy, their use is not recommended during pregnancy or in the neonatal period due to potential teratogenicity, short-term and longterm toxicity, and carcinogenicity. These serious side effects relate to the mechanism of anti-CMV action, the inhibition of DNA polymerase (Gandhi and Khanna, 2004; Mercorelli et al., 2011; Rawlinson et al., 2016). The emergence of drug-resistant CMV strains also poses a challenge (Mercorelli et al., 2011). No effective CMV vaccine is currently available (James and Kimberlin, 2016; Rawlinson et al., 2016). Therefore, novel anti-CMV strategies with alternative mechanisms of action and safer in vivo profiles are urgently needed. Valnoctamide (VCD) has been marketed since the early 1960s as an anxiolytic drug (Stepansky, 1960; Goldberg, 1961) and subsequently was tested as a mood stabilizer in patients with acute mania (Bersudsky et al., 2010). In animal models, VCD shows efficacy in both attenuating epilepsy (Lindekens et al., 2000; Isoherranen et al., 2003; Mareš et al., 2013; Pouliot et al., 2013; Shekh-Ahmad et al., 2014) and reducing neuropathic pain (Winkler et al., 2005; Kaufmann et al., 2010), in part by a mechanism that prolongs miniature IPSCs (Spampanato and Dudek, 2014). VCD shows no teratogenic effects in developing rodents (Radatz et al., 1998; Bersudsky et al., 2010; Shekh-Ahmad et al., 2014; Mawasi et al., 2015; Wlodarczyk et al., 2015; Bialer et al., 2017). Surprisingly, we recently found that VCD also inhibits CMV outside the CNS (Ornaghi et al., 2016).

Here we asked whether low-dose VCD given subcutaneously to CMV-infected neonatal mice can safely suppress CMV inside the developing brain and exert beneficial effects on neurodevelopment and behavior. We infected newborn mice on the day of birth (DOB) as a model where brain development in the newborn mouse parallels human brain development during the early second trimester of pregnancy (Clancy et al., 2001, 2007a,b; Branchi et al., 2003; Workman et al., 2013). This is a critical period of brain development where CMV can cause substantive dysfunction (Manicklal et al., 2013).

We show for the first time that VCD can protect the developing brain from CMV by both reducing the amount of virus entering the brain and by blocking viral replication and dispersal within the brain. VCD completely rescued the delayed acquisition of neurological milestones observed in infected neonatal mice. VCD treatment exerted long-lasting beneficial effects, restoring normal motor and behavioral outcomes in adolescent animals, and attenuating CMV-induced brain damage. VCD administration during critical periods of mouse brain development appeared safe and did not generate detectable adverse side effects on the neurodevelopment of uninfected control mice.

\section{Materials and Methods}

\section{Cell lines, viruses, and chemicals}

Normal human dermal fibroblasts (HDFs) were obtained from Cambrex, and primary human fetal brain astrocytes were obtained from ScienCell Research Laboratories. HDF cells were cultured in DMEM supplemented with $10 \%$ FBS and 1\% penicillin streptomycin (Pen Strep; Invitrogen). Human fetal astrocytes were grown in poly-L-lysine-coated culture vessels and maintained in Astrocyte Medium (from ScienCell Research Laboratories) supplemented with $2 \%$ FBS and $1 \%$ Pen Strep. All cultures were kept in a humidified atmosphere containing $5 \% \mathrm{CO}_{2}$ at $37^{\circ} \mathrm{C}$.

For in vitro experiments, a recombinant human CMV (hCMV, Toledo strain) expressing enhanced green fluorescent protein (EGFP) under the control of the EF1- $\alpha$ promoter (EGFP-hCMV) was used (Jarvis et al., 1999). Normal human fibroblasts were used to test viral EGFP expression, replication capability, and propagation, and to determine viral titers by plaque assay (Vieira et al., 1998; Jarvis et al., 1999).

CMV replication is species specific, and to study CMV in vivo we used a recombinant mouse CMV (mCMV; MC.55, K181 strain) that expresses EGFP (van den Pol et al., 1999), as previously reported (Ornaghi et al., 2016). NIH/3T3 cells (murine fibroblasts) were used for viral propagation and titering by plaque assay (van den Pol et al., 1999).

Recombinant CMVs were provided by Dr. E. Mocarski (Emory University, Atlanta, GA) and Dr. J. Vieira (University of Washington, Seattle, WA).

Green fluorescence was used to visualize infected cells and viral plaques. Viral titers were determined by standard plaque assay using $25 \%$ carboxymethyl-cellulose (CMC) overlay (Zurbach et al., 2014). Viral stocks were stored in aliquots at $-80^{\circ} \mathrm{C}$. For each experiment, a new aliquot of virus was thawed and used.

Valnoctamide (catalog \#V4765) was purchased from Sigma-Aldrich as powder and was dissolved in dimethylsulfoxide (DMSO) to yield a $1 \mathrm{M}$ stock solution.

\section{Quantification of infection}

Effects of VCD on hCMV infection were assessed by viral infectivity assay and viral yield reduction assay. For the infectivity assay, human fetal astrocytes were seeded at a density of 40,000 cells/well in 48-well plates and were incubated overnight before medium $(0.2 \mathrm{ml} /$ well $)$ was replaced for pretreatment with VCD or vehicle at $100 \mu \mathrm{M}$. After $1 \mathrm{~h}$ of drug exposure, cells were inoculated with hCMV [multiplicity of infection (MOI), 0.1] and incubated at $37^{\circ} \mathrm{C}$ for $2 \mathrm{~h}$ to allow viral adsorption. Following incubation, cultures were washed twice with PBS and overlaid with a viscous solution containing $\mathrm{VCD} /$ vehicle at $100 \mu \mathrm{M}$ in supplemented astrocyte medium (75\%) and CMC (25\%). GFP-positive cells were counted at $48 \mathrm{~h}$ postinfection (hpi).

In the virus yield reduction assay, after viral adsorption, cells were washed twice with PBS and replenished with fresh medium containing the compounds to be tested. At $72 \mathrm{hpi}$, medium was collected and titered by plaque assay using HDF monolayers to assess the drug-mediated inhibition of virus replication in human fetal brain astrocytes.

The total number of fluorescent cells/plaques per well in each condition were counted using an Olympus IX71 fluorescence microscope (Olympus Optical) connected to a SPOT RT digital camera (Diagnostic Instruments) interfaced with an Apple Macintosh computer. Each condition was tested in triplicate, and the whole experiment was repeated twice. Camera settings (exposure time and gain) were held constant between images. The contrast and color of collected images were optimized using Adobe Photoshop.

Viral entry analysis and quantitative real-time PCR assay

To evaluate the effects of VCD on hCMV attachment to human fetal astrocytes, prechilled cultures at $90 \%$ confluency in a six-well plate were treated with $\mathrm{VCD}$ or vehicle $(100 \mu \mathrm{M})$ for $1 \mathrm{~h}$ at $4^{\circ} \mathrm{C}$, followed by infection 
with precooled hCMV-GFP (MOI, 0.1). After $2 \mathrm{~h}$ of incubation at $4^{\circ} \mathrm{C}$, fetal astrocytes were rinsed three times with cold PBS to remove unattached virions then were harvested by trypsinization for viral DNA quantification using a quantitative real-time PCR (qRT-PCR) assay (Chan and Yurochko, 2014). To assess hCMV internalization into fetal astrocytes, cultures plated in plain media were inoculated with hCMV-GFP (MOI, 0.1) and incubated at $4^{\circ} \mathrm{C}$ for $2 \mathrm{~h}$. Cells were then washed three times to remove unbound viral particles and were exposed to VCD or vehicle at $100 \mu \mathrm{m}$ for $2 \mathrm{~h}$ at $37^{\circ} \mathrm{C}$ (to allow virus internalization) before being harvested by trypsinization for DNA quantification by qRT-PCR.

DNA was extracted from cells using the QIAamp DNA mini kit (Qiagen), and qRT-PCR was performed using TaqMan assays (Life Technologies; Gault et al., 2001; Fukui et al., 2008) for hCMV UL132 (Pa03453400_s1) and human albumin (Hs99999922_s1) genes, as previously described (Ornaghi et al., 2016). Samples from uninfected cells and without a template served as negative controls. Samples were run in duplicate using a Bio-Rad iCycler-IQ instrument, and results were analyzed with iCycler software. The amount of viral DNA in each sample relative to albumin was calculated using the comparative threshold cycle $\left(\mathrm{C}_{\mathrm{T}}\right)$ method, and hCMV DNA was expressed as the percentage of virus bound (the "attachment" step) or internalized (the "internalization" step) using DMSO-treated samples as $100 \%$.

\section{Animal procedures}

All animal breeding and experiments were performed in accordance with the guidelines of the Yale School of Medicine Institutional Animal Care and Use Committee (IACUC). Research was approved by the IACUC. Male and female BALB/c strain mice ( $6-8$ weeks of age) from Taconic Biosciences were maintained on a $12 \mathrm{~h}$ light/dark cycle under constant temperature $\left(22 \pm 2^{\circ} \mathrm{C}\right)$ and humidity $(55 \pm 5 \%)$, with access to food and water ad libitum. One to two females were cohabited with a male of the same strain for at least 1 week to ensure fertilization. When advanced pregnancy was seen, each pregnant female was caged singularly and checked for delivery twice daily, at 8:30 A.M. and 6:30 P.M. Here we focus on inoculation of the newborn mouse, similar to the strategy we recently described for studying the actions of Zika virus in the developing mouse brain (van den Pol et al., 2017).

Paradigms of $m C M V$ infection. Newborns were inoculated intraperitoneally with $750 \mathrm{pfu}$ of mCMV-GFP in $50 \mu \mathrm{l}$ of media on the DOB within $14 \mathrm{~h}$ of delivery. The DOB was considered to be postnatal day 0 (P0). Control animals received $50 \mu \mathrm{l}$ of media intraperitoneally. To avoid any litter-size effect, large litters were culled to a maximum of eight to nine pups (Tanaka, 1998). Infected and control pups were randomly assigned to receive VCD or vehicle (DMSO) via subcutaneous injections, once a day, at a dose of $1.4 \mathrm{mg} / \mathrm{ml}$ in $20 \mu \mathrm{l}$ of saline ( $28 \mu \mathrm{g} /$ mouse), starting after virus inoculation and running from P1 to P21. Mice were monitored daily for signs of mCMV-induced disease and to determine survival; weaning occurred on P21 and mice of either sex were housed separately until testing was completed, then killed.

In addition to the intraperitoneal route, intracranial injection was performed in a group of newborn mice. Three days after birth, $2 \times 10^{4}$ pfu of mCMV-GFP in $1 \mu \mathrm{l}$ of media was injected into the left cerebral hemisphere of neonatal mice under cryoanesthesia using a $10 \mu \mathrm{l}$ Hamilton syringe with a 32-gauge needle from a midpoint between the ear and eye. Infected pups were randomly assigned to receive daily doses of VCD or vehicle (DMSO), starting $3 \mathrm{~h}$ after virus inoculation until P8. No deaths occurred, and at P9 mice were killed and blood, liver, spleen, and brain were collected, snap frozen, and stored at $-80^{\circ} \mathrm{C}$ until viral titer analysis via qRT$\operatorname{PCR}(n=8$ /experimental group) was performed.

Early neurobehavioral assessment. Intraperitoneally infected pups and controls were assessed for neurobehavioral development according to a slightly modified Fox battery, as previously described (Fox, 1965; St Omer et al., 1991; Calamandrei et al., 1999). Evaluation was performed without knowledge of the experimental group on every other day from P2 to P14, in the light phase of the circadian cycle between 9:00 A.M. and 3:00 P.M. Each subject was tested at approximately the same time of the day. Reflexes and responses were scored in the following order: righting reflex, the time used by the pup to turn upright with all four feet when placed on its back; cliff aversion, when placed on the edge of a cliff or table top with the forepaws and face over the edge, the mouse will turn and crawl away from the edge; Forelimb grasping reflex, when the forefoot is stroked with a blunt instrument the foot will flex to grasp the instrument; forelimb placing reflex, contact of the dorsum of the foot against the edge of an object will cause the foot to raise and place itself on the surface of the object when the animal is suspended and no other foot is in contact with a solid surface; negative geotaxis, the time used by the pup to turn $\sim 180^{\circ}$ to either side when placed head down on a wire mesh screen $(4 \times 4 \mathrm{~mm})$ held at a $45^{\circ}$ angle; level screen test, pup holds onto a wire-mesh $(10 \times 10 \mathrm{~cm})$ and is propelled across the mesh horizontally by the tail; screen climbing test, pup climbs up a vertical screen $\left(10 \times 10 \mathrm{~cm}, 90^{\circ}\right.$ angle $)$ using both forepaws and hindpaws; maximal response, scored when the subject reaches the top of the vertical screen; and vibrissa placing reflex, when the mouse is suspended by the tail and lowered so that the vibrissae make contact with a solid object, the head is raised and the forelimbs are extended to grasp the object.

Latencies were measured in seconds using a stopwatch for righting reflex and negative geotaxis. The remaining behavioral variables were rated semiquantitatively in the following way: $0=$ no response or occurrence of the event $(\mathrm{R} / \mathrm{O}) ; 1=$ slight/uncertain $\mathrm{R} / \mathrm{O} ; 2=$ incomplete $\mathrm{R} / \mathrm{O}$; and $3=$ a complete adult-like R/O. All timed responses were limited to a maximum of $60 \mathrm{~s}$; therefore, the absence of a milestone was scored as $0 / 60 \mathrm{~s}$ (semiquantitative rating/latencies) if the mouse did not exhibit the behavior within $60 \mathrm{~s}$.

This battery of tests provides a detailed assessment of functional and neurobehavioral development throughout the neonatal period since the behaviors measured are each expressed at different stages of development during the first weeks of life. Specific information about vestibular function, motor development and activity, coordination, and muscle strength can be obtained by execution of these tests (St Omer et al., 1991; Schneider and Przewlocki, 2005).

Evaluation of motor coordination and balance in adolescent mice. Motor performance of infected and control mice, with or without VCD treatment, was assessed at P28-P30 by the hindlimb-clasping, vertical pole, and challenging beam traversal tests.

In the hindlimb-clasping test, the mouse is gently lifted by the tail, grasped near its base, and the hindlimb position is observed for $10 \mathrm{~s}$ and scored as follows: if the hindlimbs are consistently splayed outward, away from the abdomen, it is assigned a score of 0 ; if one hindlimb is retracted toward the abdomen for $>50 \%$ of the time suspended, it receives a score of 1 ; if both hindlimbs are partially retracted toward the abdomen for $>50 \%$ of the time suspended, it receives a score of 2 ; and if its hindlimbs are entirely retracted and touching the abdomen for $>50 \%$ of the time suspended, it receives a score of 3 (Tanaka et al., 2004; Guyenet et al., 2010).

The vertical pole test was conducted according to previously established protocols (Ogawa et al., 1985; Soerensen et al., 2008). Briefly, mice were individually placed head downward at the top of a vertical roughsurfaced pole (diameter, $8 \mathrm{~mm}$; height, $55 \mathrm{~cm}$ ) and allowed to descend in a round of habituation. Then, mice were placed head upward at the top of the pole. The time required for the animal to descend to the floor was recorded as the locomotor activity time $\left(\mathrm{T}_{\mathrm{LA}}\right)$, with a maximum duration of $120 \mathrm{~s}$. If a mouse fell, was unable to turn downward, or was unable to climb down, a default locomotor activity time value was recorded as $120 \mathrm{~s}$. Each mouse was given three trials with a $30 \mathrm{~s}$ recovery period between trials.

The challenging beam traversal test was performed as previously described (Fleming et al., 2004, 2013). The beam consisted of four sections ( $25 \mathrm{~cm}$ each, $1 \mathrm{~m}$ total length), each section having a different width. The beam started at a width of $3.5 \mathrm{~cm}$ and gradually narrowed to $0.5 \mathrm{~cm}$ in the last section. Underhanging ledges $(1 \mathrm{~cm}$ width) were placed $1.0 \mathrm{~cm}$ below the top surface of the beam to increase the sensitivity of the test and allow detection of subtle motor deficits (Brooks and Dunnett, 2009). Animals were trained to traverse the length of the beam starting at the widest section and ending at the narrow most difficult section. The narrow end of the beam led directly into the home cage of the animal. A bright light illuminated the start of the beam to further encourage the mouse to walk across the beam toward the home cage. Animals received $2 \mathrm{~d}$ of training before testing, with five trials for each day. On the day of the test, a mesh grid ( $1 \mathrm{~cm}$ squares) of corresponding width was placed over the beam 
surface leaving a $1 \mathrm{~cm}$ space between the grid and the beam surface. Animals were then videotaped while traversing the grid-surfaced beam for a total of five trials. Videos were viewed and rated in slow motion for hindlimb slips and time to traverse across five trials by an investigator blind to the mouse experimental group. A slip was counted when the mouse was facing and moving forward and a hindlimb slipped through or outside of the grid beyond $0.5 \mathrm{~cm}$ below the grid surface (halfway down).

Exploratory activity and social behavior anal$y$ sis. The exploratory activity was assessed in adolescent mice at P30-P40 in an adapted small open field, as previously described (Shi et al., 2003; Schneider and Przewlocki, 2005). The apparatus consisted of a plastic rectangular box measuring $20.5 \times 17 \times 13 \mathrm{~cm}^{3}(1 \times$ width $\times$ height) with regularly spaced holes in the short (2) and long (3) walls, and illuminated by ambient fluorescent ceiling lights. The animal was placed in the center of the apparatus and its movements were video recorded over a $3 \mathrm{~min}$ period. Exploratory behavior was scored for the number of rearing and nose-poking (nose of an animal put inside the hole) episodes.

Sociability and preference for social novelty were investigated at 5 weeks of age in a threecompartment apparatus (Crawley, 2007; Yang et al., 2011). Initially, test and control animals were allowed to explore the apparatus freely for a $10 \mathrm{~min}$ period (habituation). For the social approach paradigm, an unfamiliar conspecific (same sex, similar age and weight) animal was placed into one of the side compartments and restrained by a small wire object ("social cage"). The compartment on the other side contained an empty wire object ("empty cage"). The test subject was then released into the center compartment and allowed to explore the three-compartment apparatus freely for $10 \mathrm{~min}$. Behavior was videotaped and assessed for the times that the test subject spent in the three compartments and in close proximity to the social and empty cages. For the socialnovelty paradigm, another unfamiliar conspecific animal was placed in the previously empty wire object ("novel cage"). The behavior of the test mouse was recorded for $10 \mathrm{~min}$ and assessed for the time spent exploring the known and novel conspecifics.

Assessment of $m C M V$ distribution in the brain and viral-mediated brain abnormalities. At specific time points after infection, mice were killed by an overdose of anesthetic and transcardially perfused with sterile, cold PBS followed by $4 \%$ paraformaldehyde, and brains were harvested and weighed. Brains were then immersed overnight in $4 \%$ paraformaldehyde, and cryoprotected in $15 \%$ and then $30 \%$ sucrose for $24 \mathrm{~h}$ before inclusion in Tissue Freezing Medium (General Data). Some intraperitoneally infected mice became dehydrated and moribund and showed no sign of recovery; these mice were killed before the predefined killing time points and were recorded as having had a lethal response to the virus.

Fifteen-micrometer-thick sections cut with a Leica cryostat were used for GFP reporter expression assessment and immunofluorescence analysis in the brain. Sections were dried for $4 \mathrm{~h}$ at room temperature, rehydrated in $1 \times$ PBS, and then used for immunofluorescence assays. Briefly, tissue sections were incubated overnight at $4^{\circ} \mathrm{C}$ with monoclonal mouse anti-NeuN antibody (1:500; catalog \#MAB377, EMD Millipore; RRID:
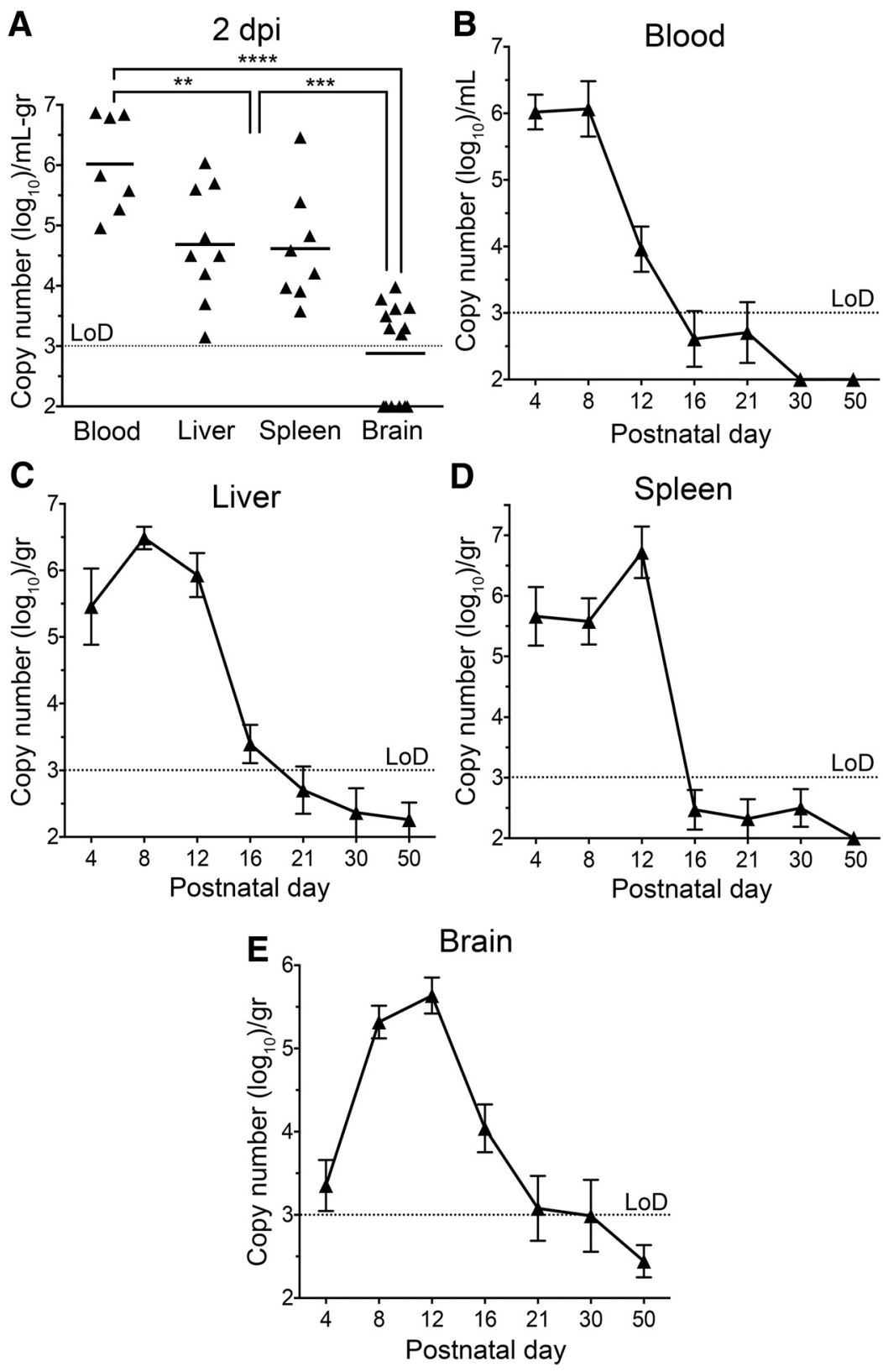

Figure 1. Kinetics of $\mathrm{mCMV}$ replication after intraperitoneal inoculation on day of birth. Newborn mice were infected on the DOB (day 0) with 750 pfu of mCMV. Viral load in whole blood, liver, spleen, and brain was evaluated by qRT-PCR at the indicated time points and expressed as $\log _{10}$ genome copies per gram $/ \mathrm{ml}$ of harvested tissue/blood. In $\boldsymbol{A}$, each symbol represents an mice/time point. Viral titers below the limit of detection (LoD, dotted line) were plotted as $2 \log _{10}$ genome copies. In $A^{* *} p<0.01,{ }^{* * *} p<0.001,{ }^{* * * *} p<0.0001$; one-way ANOVA with Bonferroni's post hoc test.

AB_2298772) for neuronal cells and polyclonal rabbit anti-calbindin D-28K (1:500; catalog \#AB1778, EMD Millipore; RRID: AB_2068336) for cerebellar Purkinje cells (PCs). Tissues were washed three times in phosphate buffer plus $0.4 \%$ Triton X-100. Secondary antibodies, including goat anti-mouse IgG and donkey anti-rabbit IgG conjugated to Alexa Fluor-594 (1:250; Invitrogen), were applied for $1 \mathrm{~h}$ at room temperature and then washed off. Some sections were labeled with DAPI. Vectashield Fluorescent mounting medium (Vector Laboratories) was then used for mounting.

Images were collected by using a fluorescence microscope (model IX 71, Olympus Optical).

Frozen sections were used for morphometric measurements, and cell numbers were quantified after imaging using ImageJ software (https:// imagej.nih.gov/ij/; RRID: SCR_003070). The molecular layer (ML) and 

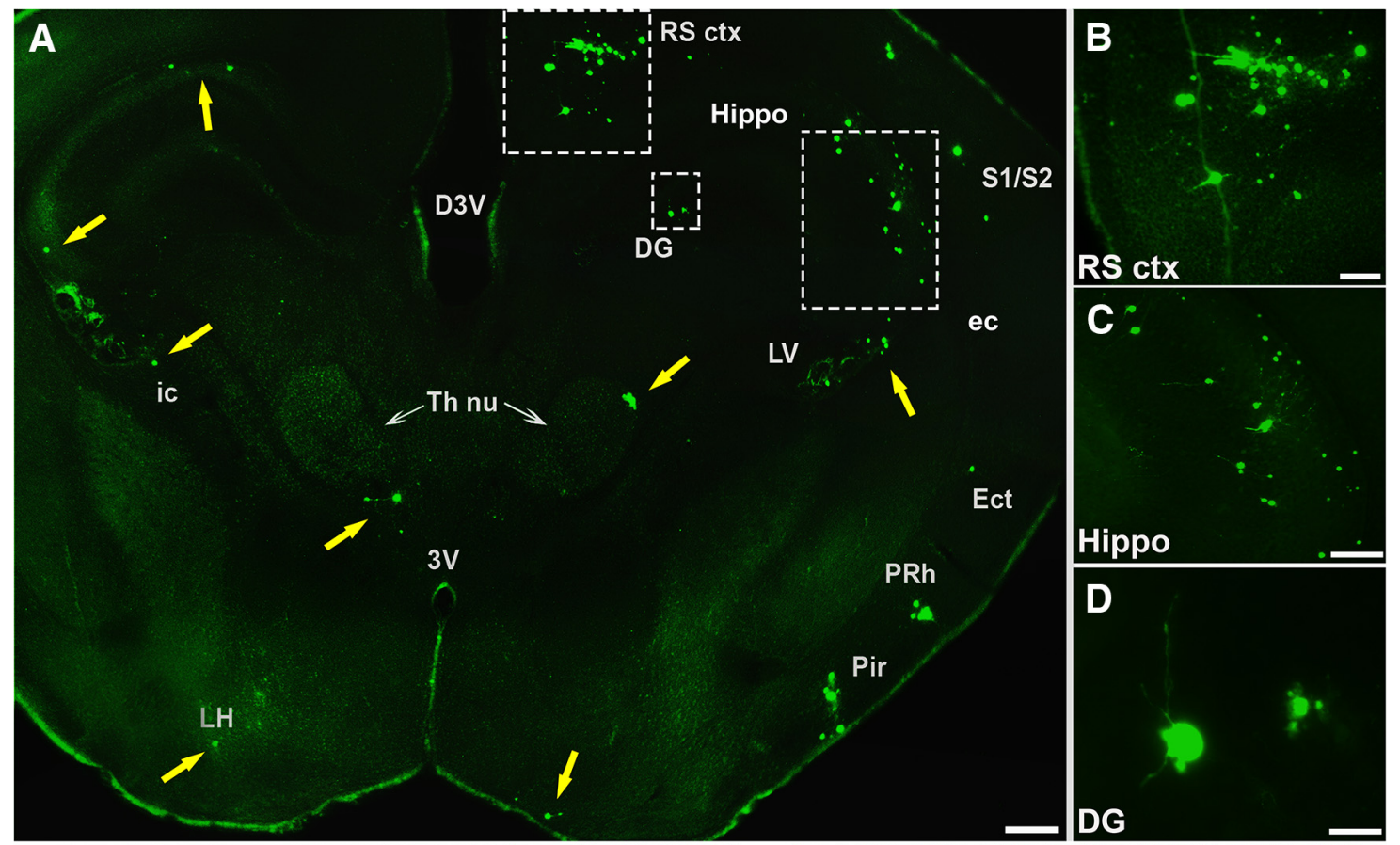

LV
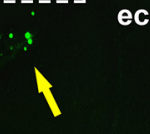

Ect
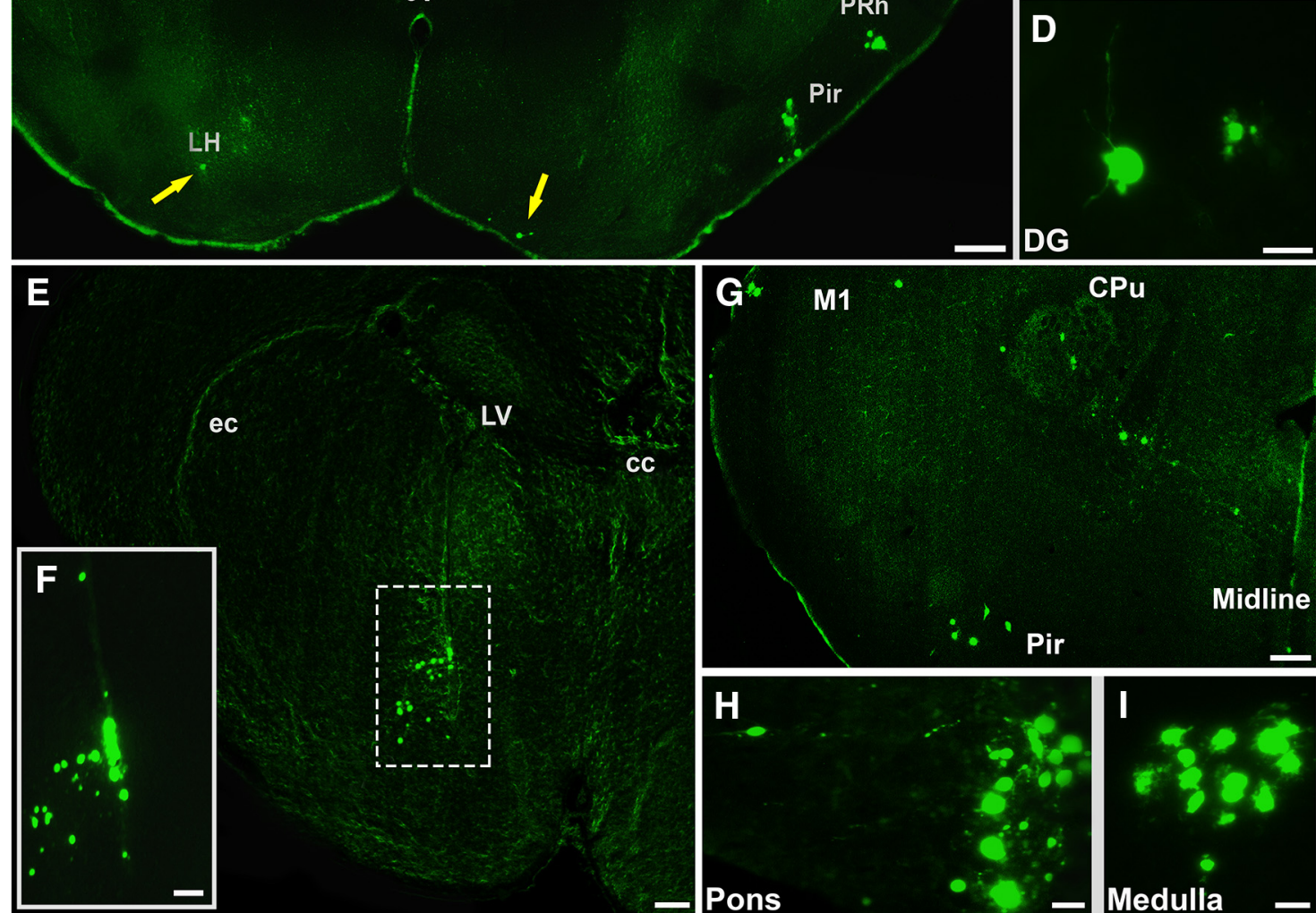

LV

ec

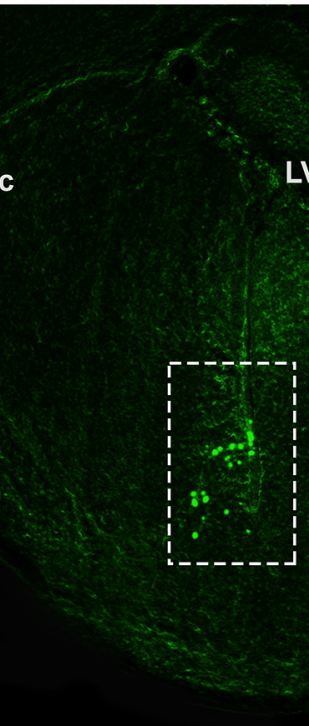

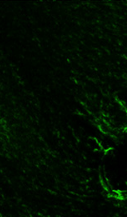

Figure 2. Scattered widespread distribution of $m$ CMV-GFP in brains after infection of newborn mice. Detection of virus-infected cells by means of mCMV GFP reporter expression in representative coronal sections of P8 and P12 mouse brains $(n=5)$. A, Single infected cells or small foci of infection (yellow arrows) can be identified in the retrosplenial cortex (RS ctx), primary and secondary somatosensory cortex (S1/S2), ectorhinal cortex (Ect), perirhinal cortex (Prh), piriform cortex (Pir), hippocampus (hippo) and dentate gyrus (DG), lateral ventricle (LV), external and internal capsule of the corpus callosum (ec and ic, respectively), lateral hypothalamic area (LH), and thalamic nuclei (Th Nu) of a P12 mouse brain. D3V, dorsal third ventricle. $\boldsymbol{B}-\boldsymbol{D}$ are magnifications of the boxed areas in $\boldsymbol{A} . \boldsymbol{E}$, Infection of the lateral ventricle and diffusion to the adjacent brain parenchyma in a P8 brain. $\boldsymbol{F}$, Magnification of the boxed area in $\boldsymbol{E}$. cc, corpus callosum. $\boldsymbol{G}$, Photomicrograph of a P12 brain showing infection in the motor (M1) and piriform cortex, and in the striatum [caudate-putamen (CPu)]. $\boldsymbol{H}, \boldsymbol{I}$, Large foci of mCMV-infected cells in the pons and the medulla of a P8 animal. Scale bars: $\boldsymbol{H}, 50 \mu \mathrm{m} ; \boldsymbol{A}, \boldsymbol{D}, \boldsymbol{E}, \boldsymbol{G}, \boldsymbol{I}, 100 \mu \mathrm{m} ; \boldsymbol{C}, \boldsymbol{F}, 200 \mu \mathrm{m} ; \boldsymbol{B}, 400 \mu \mathrm{m}$.

internal granular layer (IGL) were assessed using images of serial midsagittal cerebellar sections stained with calbindin D-28K and DAPI. Three measurements were taken at each side of the primary fissure in each section, and four sections per animal were evaluated. For the cerebellar area, midsagittal brain sections (three sections/mouse) were stained with blue fluorescent Nissl stain (NeuroTrace, catalog \#N21479, Thermo Fisher Scientific), and images were collected using a $2 \times$ objective. Cell counts were performed on sections (four sections/mouse) stained with calbindin D-28K, and the number of Purkinje cells was evaluated along $500 \mu \mathrm{m}$ of the primary fissure (both sides). All measurements and quantifications were performed on at least five animals from three different litters.

Kinetics of virus spread and replication in vivo. For measurement of mCMV replication in blood, liver, spleen, and brain, mCMV-infected mice receiving either VCD or vehicle intraperitoneally or intracranially were killed at multiple time points postinoculation, and samples were collected under sterile conditions, snap frozen, and stored at $-80^{\circ} \mathrm{C}$ until viral titer analysis via quantitative real-time PCR ( $n=7-10 /$ experimental group) was performed. Mice used for viral load analysis in liver, spleen, and brain were perfused with sterile cold PBS to remove any virus contained within the blood. Total DNA was isolated using the QIAamp DNA Mini Kit (Qiagen) as per manufacturer instructions. Quantitative PCR was performed using TaqMan assays (Life Technologies) by amplification of a fragment of mCMV IE1 gene exon 4 using the following primers: forward, $5^{\prime}$-GGC TTC ATG ATC CAC CCT GTT A-3'; and reverse, 5' -GCC TTC ATC TGC TGC CAT ACT-3'. The probe (5' -AGC CTT TCC TGG ATG CCA GGT CTC A-3') was labeled with the reporter 


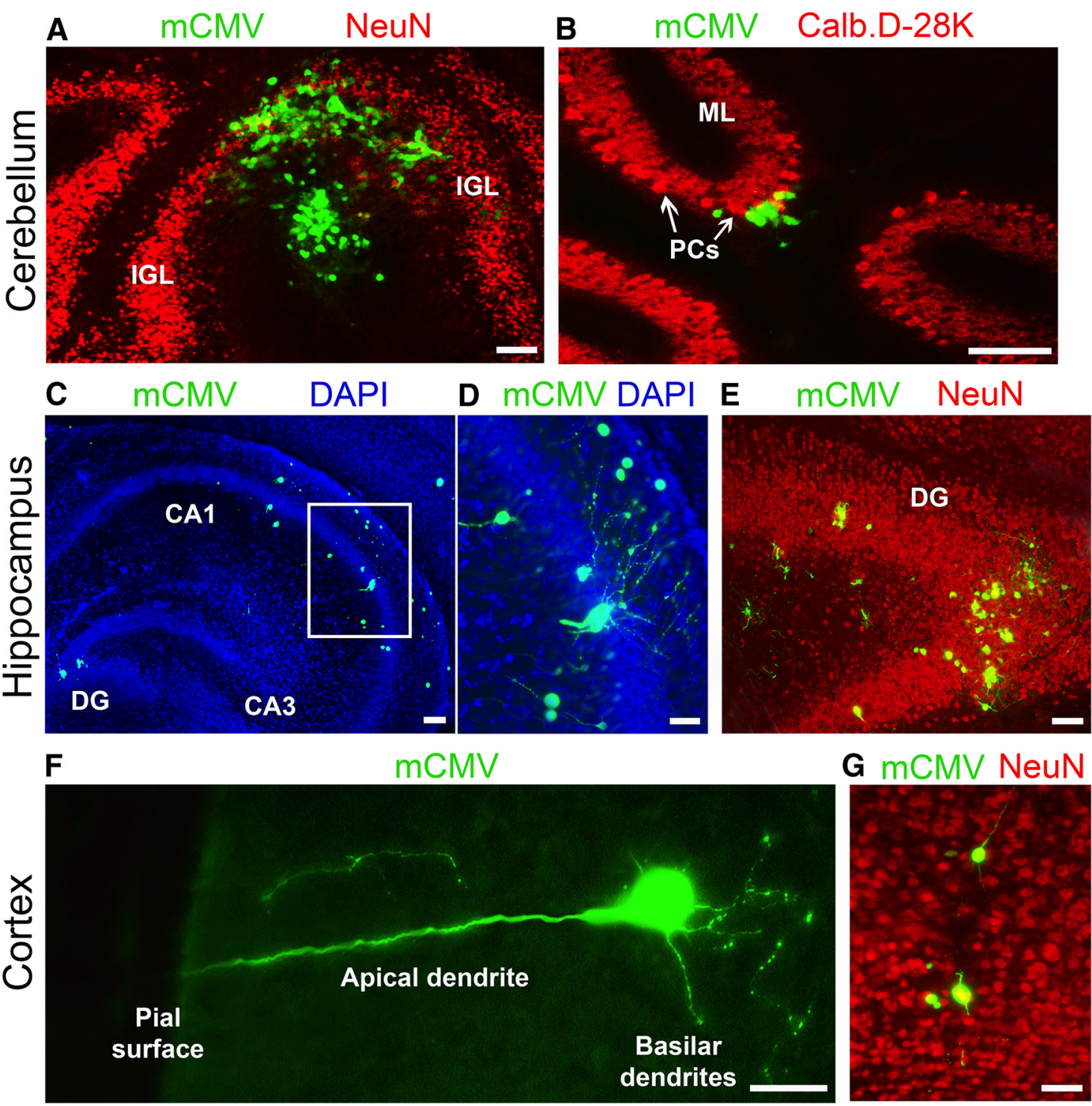

Figure 3. CMV infection of neuronal cells in the cerebellum, hippocampus, and cortex of the developing brain. $A, B$, Photomicrographs show GFP labeling of different cerebellar cell types, including neurons in the internal granular layer $(\boldsymbol{A})$ and Purkinje cells $(\boldsymbol{B})$, as assessed by NeuN and calbindin D-28K staining at $8 \mathrm{dpi}$ ( $n=2$ brains). $(-\boldsymbol{E}$, Photographs display infection of different areas of the hippocampus $(\boldsymbol{C}$, a magnification of the viral involvement of pyramidal cells in CA1 field (boxed area; $\boldsymbol{D}$ ), and infected neurons in the dentate gyrus (DG; $n=2$ brains; $\boldsymbol{E}$ ). $\boldsymbol{F}$, Robust GFP expression in a pyramidal neuron of the motor cortex ( $n=1$ brain); note the beaded aspect of the basilar dendrites, sign of neuronal pathology. Photomicrograph of neuronal infection in the visual cortex $(n=1$ brain; $\mathbf{G})$. Scale bars: $\mathbf{A}-\boldsymbol{E}, \mathbf{G}, 100 \mu \mathrm{m} ; \boldsymbol{F}, 50 \mu \mathrm{m}$.

dye FAM (Kosmac et al., 2013). qRT-PCR was performed using $20 \mu \mathrm{l}$ reaction mixtures using the iTaq Universal SYBR Probes Supermix (Bio$\mathrm{Rad}$ ) and $100 \mathrm{ng}$ of DNA. Samples were run in duplicate using a two-step amplification protocol. Tissue samples from uninfected mice and samples without a template served as negative controls. Viral burden was expressed as the copy number per ml per gram blood/tissue after comparison with a standard curve generated using serial 10-fold dilutions of mCMV DNA.

\section{Experimental design and statistical analysis}

Statistical significance, unless otherwise specified, was determined by one-way ANOVA or Kruskal-Wallis test followed by Bonferroni's and Dunn's post hoc test, respectively, for evaluation of motor performance, exploratory behavior, and brain morphometry. Early neurobehavioral development, social behavior, and viral load over time were assessed by a mixed-model ANOVA with repeated measures followed by NewmanKeuls test if there was a significant $F$ value. Since no gender-related differences were detected in early neurodevelopment, data from male and female mice were combined. Only male mice were used for exami- nation of motor performance and exploratory and social behavior. All analyses were conducted with GraphPad Prism version 6.0 (RRID: SCR_002798), with significance set at $p<0.05$. Neurobehavioral assessment was performed blindly with respect to the experimental group.

\section{Results}

Peripheral inoculation of CMV causes widespread infection of the developing brain

First, we characterized the kinetics of CMV replication and dissemination after intraperitoneal inoculation of the virus in newborn mice on the DOB (P0). Forty-eight hours after intraperitoneal injection, CMV was found in the blood and at lower levels in the spleen and liver of infected mice, with only a small amount detected in the brain (Fig. 1A). Analysis of viral kinetics in these four organs over the course of $50 \mathrm{~d}$ revealed that CMV, after entering the bloodstream, quickly gained access to peripheral target organs (i.e., the liver and spleen) and began replicating to yield high viral titers by $4 \mathrm{~d}$ post-injection (dpi; Fig. $1 B-D)$. In 


\section{Intraperitoneal $\mathrm{mCMV}$ inj. at P0}

A
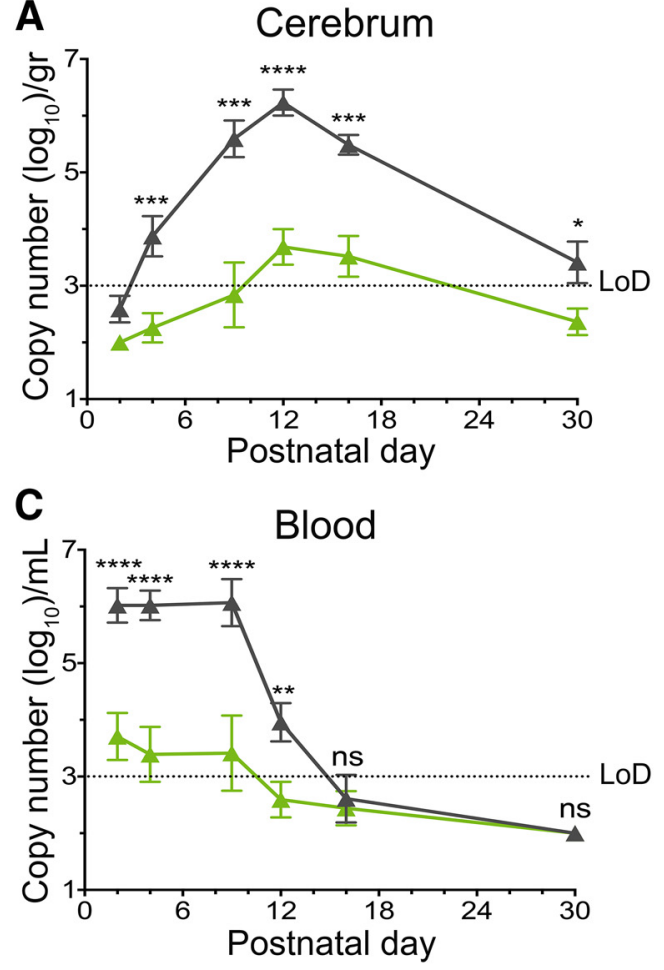
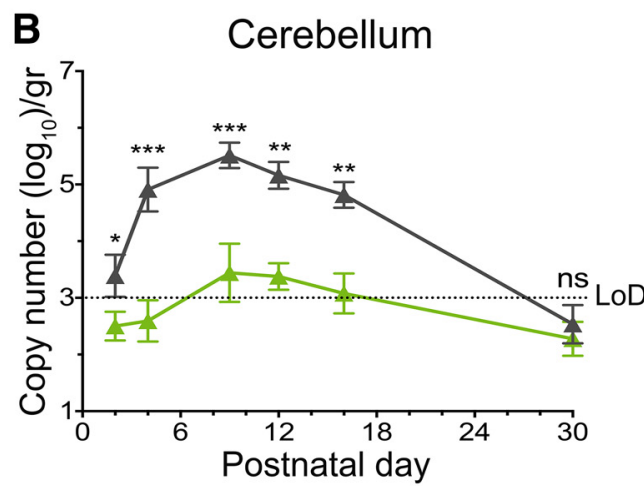

D Liver

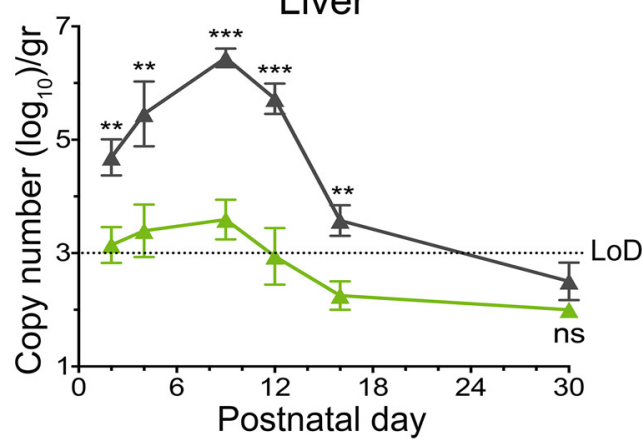

E

Spleen

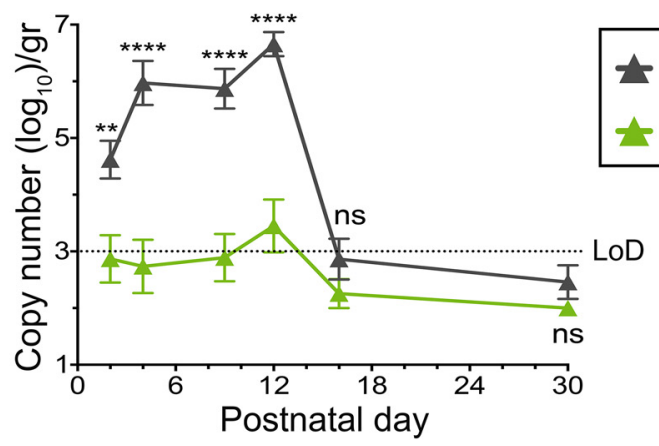

$\mathrm{mCMV}+\mathrm{VEH}$

$m C M V+V C D$

Figure 4. Valnoctamide suppresses mCMV load in the brain of mice infected intraperitoneally on the day of birth. Newborn mice were infected at PO with $750 \mathrm{pfu}$ of $\mathrm{mCMV}$ intraperitoneally and were randomized to receive either vehicle (mCMV+VEH) or VCD $(m C M V+V C D)$ subcutaneously from P1 until P21. $A-\boldsymbol{E}$, Viral load was quantified in the cerebrum $(\boldsymbol{A})$, cerebellum $(\boldsymbol{B})$, whole blood $\left(\boldsymbol{C}\right.$, liver $(\boldsymbol{D})$, and spleen $(\boldsymbol{E})$ by qRT-PCR at the specified time points and were expressed as $\log _{10}$ genome copies per gram $/ \mathrm{ml}$ harvested tissue/blood. Data are presented as the mean \pm SEM; $n=$ 7-10 mice/time point. Viral titers below the limit of detection (LoD, dotted line) were plotted as $2 \log _{10}$ genome copies. ns, Not significant. ${ }^{*} p<0.05,{ }^{* *} p<0.01$, ${ }^{* * *} p<0.001$, **** $<0.0001$; two-way ANOVA with postnatal day as repeated measures.

turn, similar viral titers were measured in the brain only after 8 dpi (Fig. 1E). After entering the brain, the virus could effectively replicate in situ, as suggested by the measurement of CMV loads similar to those found in the liver and spleen at the viral peak between P8 and P12 (Fig. 1C-E).

Upon histological examination, CMV-GFP infection of the developing mouse brain appeared widespread and scattered in nature. Isolated infected cells and infectious foci containing up to $20-25$ cells could be found in multiple distant areas within the same brain. The pattern of infection also appeared heterogeneous, with different brains displaying infection in different regions. These observations are consistent with a hematogenous spread of CMV from the periphery into the developing brain of neonatal mice. Infected cells were identified in the olfactory bulb and nuclei, the cortex, corpus callosum, hippocampus, basal nu- clei, choroid plexus, midbrain, superior and inferior colliculi, sylvian aqueduct, pons, medulla, cerebellum, and meninges (Fig. $2 A-I)$. No CMV was detected in the spinal cord. Infection of the choroid plexus in the lateral ventricles was frequently associated with evidence of infected cells in the brain parenchyma in close proximity to the ventricle (Fig. 2E,F), a site of neural progenitor stem cell localization (Semple et al., 2013). Infection of certain brain areas, such as the thalamus and the hypothalamus, was observed less frequently compared with other regions, including the cerebellum, hippocampus, and cortex. The cerebellum was the only site consistently displaying viral infection in all the brains examined $(n=20)$, with robust GFP labeling in both Purkinje cells and granule neurons (Fig. $3 A, B$ ). Viral GFP was also identified in neurons of the hippocampus and in the cerebral cortex (Fig. 3C-G). In cortical pyramidal cells, GFP was seen in both the 
apical dendrite extending toward the cortical surface and in basal dendrites ramifying closer to the cell body. Some infected neurons in the cortex displayed signs of degeneration, characterized by abnormal swelling along the dendrites (Fig. $3 F$ ).

Together, these results indicate that intraperitoneally administered CMV, after replicating in peripheral target organs, enters the developing brain of neonatal mice via the bloodstream or immune cells in the blood, producing a scattered and widespread infection with a highly heterogeneous pattern of propagation. Nonetheless, CMV appears to display a particular preference for the cerebellum as an infectious site.

\section{Subcutaneous valnoctamide blocks CMV replication within the brain}

Mice were infected intraperitoneally on the day of birth, and we compared the brains of infected mice treated subcutaneously with VCD with nontreated CMV-infected mice. CMV load in the brain was quantified at multiple time points after virus inoculation. Cerebrum (cortex, hippocampus, thalamus, hypothalamus, and striatum) and cerebellum were assessed separately to determine whether the viral preference for the cerebellar region, as observed in the brain section analysis, was also accompanied by higher levels of virus replication. VCD decreased the amount of virus detected in both the cerebrum and cerebellum by a very substantial amount, with an $\sim 100$ - to 1000 -fold decrease at all time points tested (Fig. 4A,B). The anti-CMV effect displayed a rapid onset, suppressing the viral load after only 1 and $3 \mathrm{~d}$ of treatment in the cerebellum and the cerebrum, respectively. In untreated infected mice, higher viral titers were identified in cerebellar samples compared with cerebrum at the beginning of infection (P4: $t=3.704, p=0.004$, paired Student's $t$ test), suggesting that the cerebellum may represent a preferential site for initial CMV targeting in the brain. These data indicate that VCD can attenuate CMV infection detected in the brain. The observed antiviral effect of VCD in the CNS could be the consequence of a drug-mediated decrease in viral replication in the periphery. Along this line, we corroborated (Ornaghi et al., 2016) that VCD also attenuated CMV in the blood, liver, and spleen, starting quickly after therapy initiation and continuing to the end of the experiment (Fig. 4C-E). This reduction of CMV outside the brain would benefit the brain by reducing the amount of virus that ultimately can enter the CNS.

To investigate whether VCD can act directly in the brain to decrease CMV, we infected pups on P3 by direct intracranial virus inoculation. Analysis of CMV load in the blood, liver, and spleen of untreated infected mice at P9 showed no viral spread outside the CNS (data not shown). Viral titers in the cerebrum and the cerebellum were substantially lower by $>100$-fold in CMV-infected animals receiving VCD treatment compared with untreated CMV-infected mice $\left(2.99 \times 10^{5} \pm 9.06 \times 10^{4}\right.$ vs $2.47 \times 10^{8} \pm 1.22 \times 10^{8}$ copy number/g tissue, $p=0.004$ in cerebrum; $2.88 \times 10^{6} \pm 1.83 \times 10^{6}$ vs $3.41 \times 10^{8} \pm 1.52 \times 10^{8}$ copy number/g tissue, $p=0.0003$ in cerebellum; Mann-Whitney $U$ test; Fig. 5). These results indicate that subcutaneously administered low-dose VCD can enter the brain at sufficient concentrations to effectively suppress CMV replication in situ.

\section{Reversal of early neurological dysfunction in CMV-infected neonatal mice}

Human infants with CMV infection during early development can display substantial delays in the acquisition of neurological milestones during the first months of life (Dollard et al., 2007; Kimberlin et al., 2015). Since VCD showed a robust antiviral

\section{Intracranial mCMV inj. at P3}

Cerebrum Cerebellum

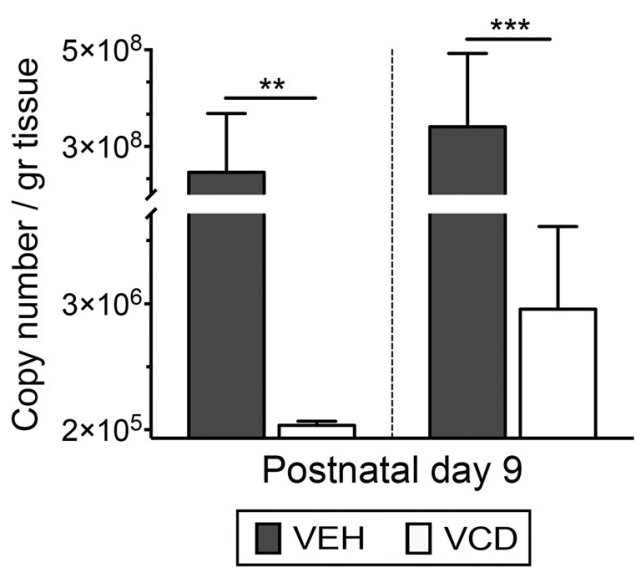

Figure 5. Subcutaneously injected valnoctamide enters the brain and suppresses mCMV replication within the brain. Quantification of $\mathrm{mCMV}$ load in the brain of mice intracranially infected with $2 \times 10^{4} \mathrm{pfu}$ of $\mathrm{mCMV}$ on day 3 after birth. The amount of virus in the cerebrum (left) and the cerebellum (right) was calculated by qRT-PCR in $P 9$ mice receiving either vehicle (VEH) or VCD subcutaneously from $\mathrm{P} 3$ through $\mathrm{P} 8$ and expressed as genome copies per gram of harvested tissue. Values are reported as the mean \pm SEM; $n=8$ mice/time-point. ${ }^{* *} p<0.01$, ${ }^{* * *} p<0.001$, Mann-Whitney $U$ test.

activity in the CNS of infected mice with a rapid attenuation of viral replication, we investigated whether this would translate into a positive therapeutic effect on the early neurological outcomes of neonatal mice.

Neurobehavioral assessments were performed using a battery of tests to examine body righting and tactile reflexes, motor coordination, and muscular strength. These tests provide a detailed examination of neurontogeny throughout the neonatal period since the behaviors measured are each expressed at different periods during the first 3 weeks of postnatal life (Fox, 1965; Scattoni et al., 2008).

Here and in a number of experiments below, we compared neurological function in the following four groups of mice: noninfected controls; VCD-treated non-infected controls; CMVinfected mice; and CMV-infected mice treated with VCD. VCD was administered in a single daily subcutaneous dose (for additional details, see Materials and Methods).

CMV infection on the day of birth induced abnormal acquisition of all the neurological milestones assessed, with infected mice showing a delay of 6-10 $\mathrm{d}$ in the demonstration of responses similar to the uninfected controls (Fig. 6A-H). In turn, infected VCD-treated neonatal pups displayed a timely acquisition of neurological milestones in all the behaviors measured. No differences were identified in the early neurontogeny of uninfected mice receiving VCD or vehicle. Together, these data indicate that VCD treatment during early development can safely improve the short-term neurodevelopmental outcomes observed in infected neonatal mice.

\section{Amelioration of long-term neurobehavioral outcomes in infected juvenile mice}

CMV infected infants with evidence of neurological delays during the neonatal period are at increased risk of the development of long-term permanent neurological and behavioral sequelae, which manifest with a delayed onset after the first years of life (James and Kimberlin, 2016). Abnormal motor function is a 
A

Righting reflex

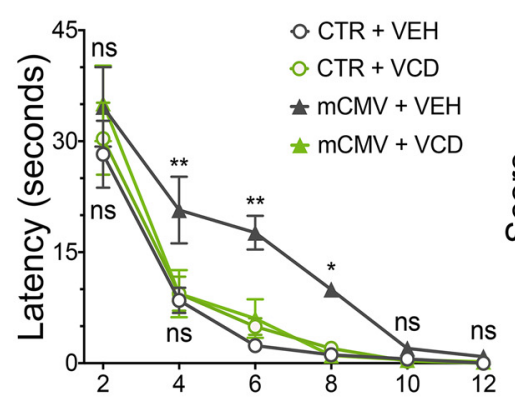

C Grasping reflex

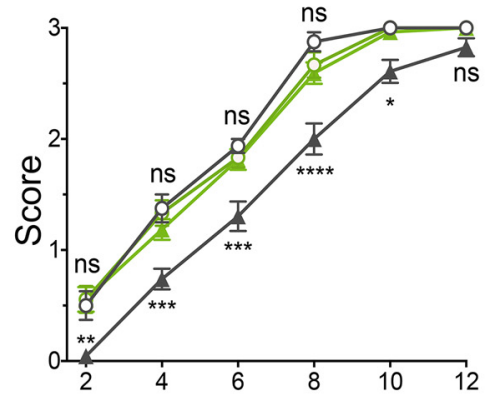

E Negative geotaxis

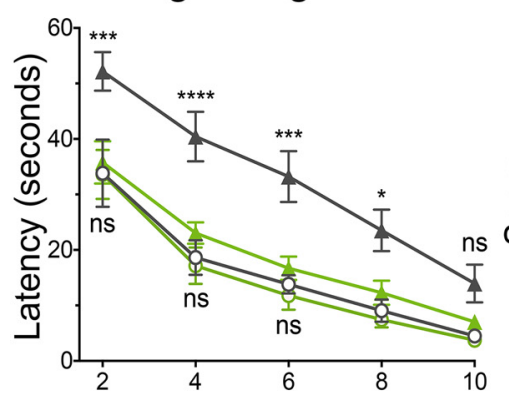

G Screen climbing test

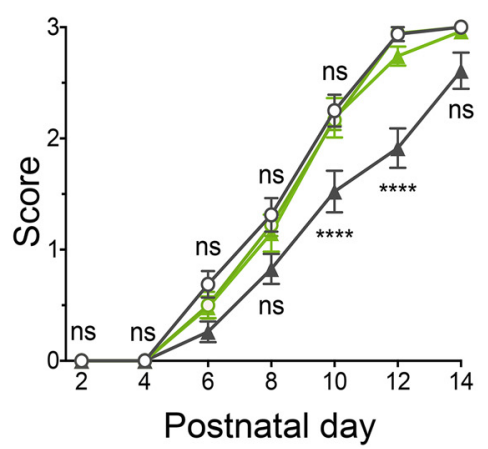

B Cliff aversion

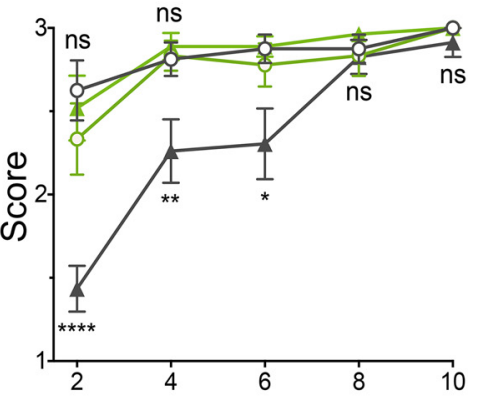

D Placing reflex

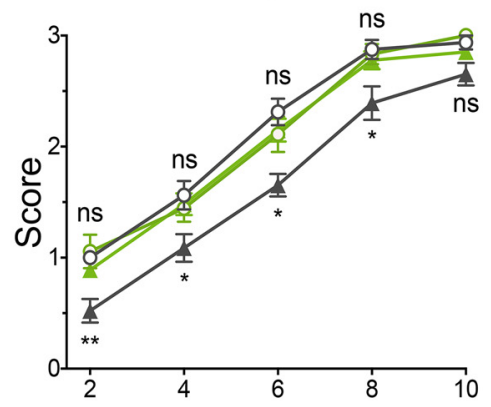

F Level screen test

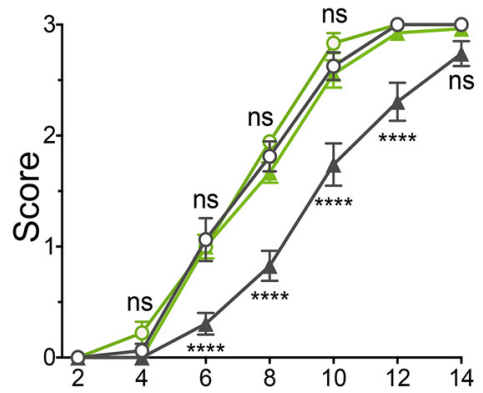

Vibrissa placing reflex

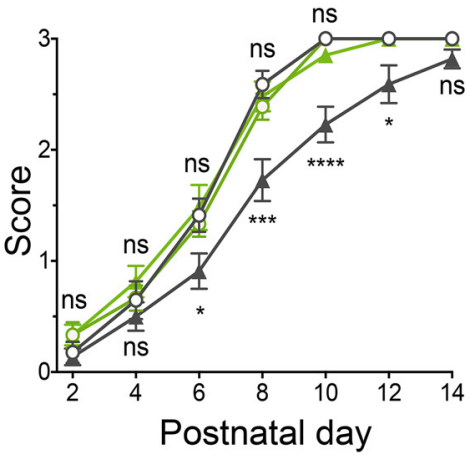

Figure 6. Delayed acquisition of neurological milestones induced by $\mathrm{mCMV}$ infection is completely rescued by valnoctamide therapy. $\boldsymbol{A}-\boldsymbol{H}$, Graphs show neurodevelopmental delays in $\mathrm{m}(\mathrm{CMV}$-infected pups (solid gray triangles) as assessed by the righting reflex $(\boldsymbol{A})$, the cliff aversion $(\boldsymbol{B})$, the forelimb grasping and placing reflex $(\boldsymbol{C}, \boldsymbol{D})$, the negative geotaxis $(\boldsymbol{E})$, the level screen test $(\boldsymbol{F})$, the screen climbing test $(\boldsymbol{G})$, and the vibrissa placing reflex $(\boldsymbol{H}$; for a detailed description, see Materials and Methods). VCD-treated animals (solid green triangles) showed neurological responses similar to uninfected controls receiving either vehicle (VEH; empty gray circles) or VCD (empty green circles). Values are reported as the mean \pm SEM, $n=20-24$ mice $\left(9-12\right.$ males)/experimental group. ns, Not significant. ${ }^{*} p<0.05,{ }^{* *} p<0.01,{ }^{* * *} p<0.001$, ${ }^{* * * *} p<0.0001$; two-way ANOVA with postnatal day as repeated measures. Significance is shown next to the infected, untreated mice ( $m C M V+V E H)$ line for comparison with uninfected controls (CTR + VEH and CTR + VCD) and next to control lines for comparison with VCD-treated infected pups ( $m C M V+V C D)$.

commonly observed long-term neurological complication (Turner et al., 2014). More recently, a link between ASD-like behavioral disturbances in children and adolescents and CMV infection during early development has been proposed (Sakamoto et al., 2015; Garofoli et al., 2017). Given the substantial improvement induced by VCD in the early neurontogeny of CMV-infected neonatal mice, we examined whether these beneficial effects could also ameliorate late-onset neurobehavioral abnormalities, including motor performance and social and exploratory behavior.

\section{Motor performance}

As indicated above, the cerebellum appears to be a preferential site for CMV targeting in the mouse brain. We investigated cerebellar-mediated motor functions in infected and control juvenile mice using a hindlimb-clasping test, a vertical pole test, and a challenging beam traversal test (Brooks and Dunnett, 2009; Guyenet et al., 2010; Fleming et al., 2013).

The hindlimb clasping test is a marker of cerebellar pathology commonly used for severity scoring in mouse models of cerebellar degeneration (Guyenet et al., 2010). The majority of the CMV-infected mice ( 9 of 13 mice) displayed an abnormal response to the clasping test, with both hindlimbs partially or entirely retracted to the abdomen when the mice were suspended by their tail for $10 \mathrm{~s}$ (Fig. $7 A, B)$. VCD administration completely reversed this altered behavior, restoring a response similar to the uninfected counterparts.

By placing a mouse head upward on a vertical wooden pole, the vertical pole test allows for the examination of the ability of the animal to turn through $180^{\circ}$ and successfully climb down the pole (Brooks and Dunnett, 2009). CMV-infected, untreated juvenile mice required a longer period to complete the task compared with both uninfected controls and CMV-infected VCD-treated animals (Fig. 7C). Three of 20 infected mice (15\%) without treatment failed the test (e.g., showed an inability to turn the head downward or falling) in all of the three trials given, whereas no VCDtreated infected mice or uninfected controls failed in performing the task ( $p=$ 0.03, $\chi^{2}$ test).

In addition, we evaluated fine motor coordination and balance by the challenging beam traversal test, which assesses the ability of a mouse to maintain balance while traversing a narrow, 1-m-long beam 
to reach a safe platform (Carter et al., 2001; Brooks and Dunnett, 2009; Luong et al., 2011; Fleming et al., 2013). CMV infection during early development increased the time needed by the mice to cross the beam and also the frequency of slipping (Fig. 7D,E). VCD treatment significantly improved the coordination and balance of CMV-infected mice, reducing both the beam traversal time and the number of slips recorded.

\section{Social and exploratory behavior}

ASD is characterized by pervasive impairments in social interactions coupled with restricted and repetitive behaviors and decreased exploratory activity (American Psychiatric Association, 2013). To investigate whether adolescent mice with perinatal CMV infection would display social and exploratory behavioral disturbances, we assessed social interaction and novel environment exploration by means of the three-chamber test and an adapted small open field test.

Infected untreated mice showed normal sociability when exposed to a first stranger mouse, preferring the conspecific over the empty cage (novel object; Fig. $8 A$ ). However, a lack of preference for social novelty was found when a second stranger mouse was introduced, with infected untreated mice spending an equal amount of time in investigating the known and the novel animal (Fig. 8B). VCD therapy restored social novelty responses similar to levels shown in uninfected controls, with increased time devoted to examining the second stranger mouse.

Exploratory activity was assessed by quantifying the number of rearings and nose pokings of mice exposed to a novel environment over a 3 min test session (Fig. 8C,D). A substantial reduction in both rearing and hole-poking events was identified in CMV-infected untreated mice compared with control animals. Normal levels of exploratory activity were restored in infected mice receiving VCD treatment.

\section{Valnoctamide attenuates CMV-induced} brain defects in early development

Early-onset neurodevelopmental delays and long-term permanent neurobehavioral disabilities are commonly observed in CMV-infected babies with evidence of virally induced brain abnormalities, including decreased brain size and cerebellar hypoplasia (Gandhi and Khanna, 2004; de Vries et al., 2004; Cheeran et al., 2009; Oosterom et al., 2015; James and Kimberlin, 2016). Since VCD showed a potent and fast-acting anti-CMV activity in the brains of infected mice and appeared
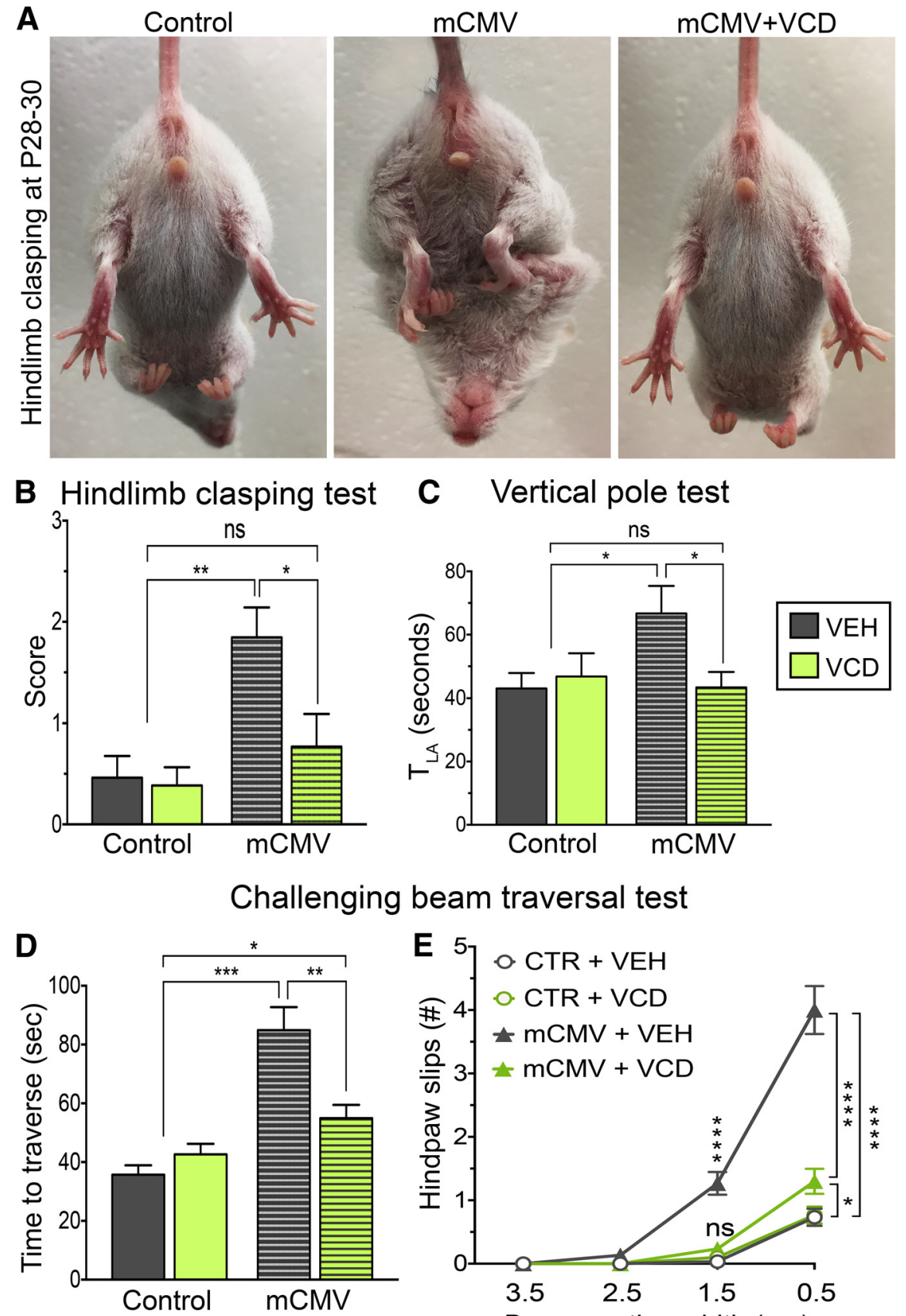

Figure 7. Impaired cerebellar-mediated motor functions in mCMV-infected mice are ameliorated by valnoctamide treatment. $\boldsymbol{A}$, Photographs display stereotypical clasping response with hindlimbs retracted to the abdomen in an mCMV-infected mouse (middle), and a normal response with splayed out hindlimbs in an uninfected control (left) and in an mCMV-infected, VCD-treated animal (right). $\boldsymbol{B}$, Scoring of clasping response according to hindlimb position. $\boldsymbol{C}$, Increased $T_{L A}$ in infected, untreated mice in the vertical pole test, compared with VCD-treated infected animals and uninfected controls. $\boldsymbol{D}, \boldsymbol{E}$, Investigation of fine motor coordination and balance by challenging beam traversal test. Infected mice need more time to traverse the beam $(\boldsymbol{D})$ and slip more $(\boldsymbol{E})$ than the control mice. Both aspects are improved by VCD administration. Values are reported as the mean \pm SEM; $n=10-13$ mice/group. ${ }^{*} p<0.05,{ }^{* *} p<0.01,{ }^{* * *} p<0.001,{ }^{* * *} p<0.0001$; Kruskal-Wallis test with Dunn's post hoc test in $\boldsymbol{B}-\boldsymbol{D}$, and two-way ANOVA with repeated measures and Bonferroni's post hoc comparison in $\boldsymbol{E}$.

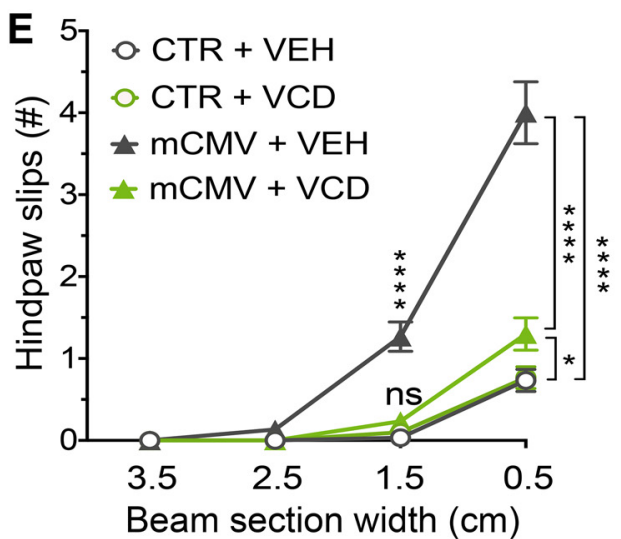

beneficial to both short- and long-term neurobehavioral outcomes, we investigated whether drug treatment during early development could also exert therapeutic actions on CMV-induced brain defects.

Brain size was analyzed in 1-month-old-mice by assessing the brain-to-body weight ratio (Fig. 9A,B). This measurement allows a more objective evaluation of the postnatal brain growth, 

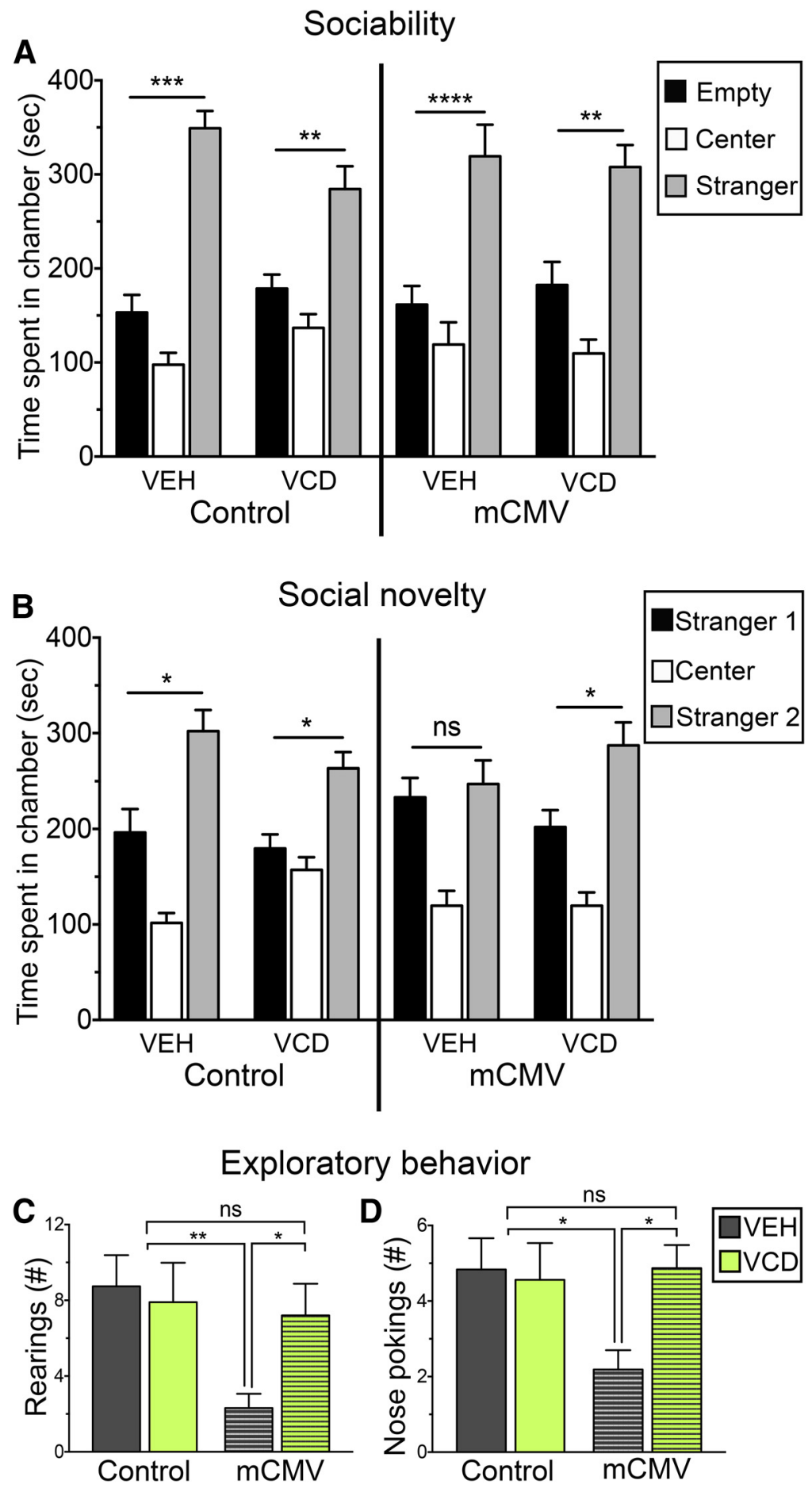

Figure 8. CMV infection during early development causes disturbances in social behavior and exploratory activity in adolescent mice. $\boldsymbol{A}, \boldsymbol{B}$, Sociability $(\boldsymbol{A})$ and preference for social novelty $(\boldsymbol{B})$ assessment in infected and control mice, with or without VCD treatment, by means of the three-chamber test. CMV-infected mice display regular sociability compared with control mice but lack a preference for a novel mouse over a known mouse. This lack of preference for social novelty is restored by VCD administration. $\boldsymbol{C}, \boldsymbol{D}$, Exploratory activity was assessed by quantification of rearing $(\boldsymbol{C})$ and nose-poking $(\boldsymbol{D})$ events in a novel environment. The altered exploratory behavior with decreased number of events identified in $\mathrm{mCMV}$-infected animals is rescued by VCD. Values are reported as the mean \pm SEM; $n=10-13$ mice/group for social behavior, $n=18-22$ mice/group for exploratory activity. ns, Not significant. ${ }^{*} p<0.05,{ }^{* *} p<0.01,{ }^{* * *} p<0.001,{ }^{* * * *} p<0.0001$; two-way ANOVA with repeated measures and Bonferroni's post hoc comparison in $\boldsymbol{A}$ and $\boldsymbol{B}$, Kruskal-Wallis with Dunn's post hoc test in $\boldsymbol{C}$ and $\boldsymbol{D}$.

compared with absolute brain weight, when somatic growth restriction is present. Subcutaneous VCD rescued the deficient brain growth induced by CMV, restoring brain-to-body weight ratio values similar to those in uninfected control mice.
Hypoplasia of the cerebellum is a common radiological finding in CMVinfected human babies (de Vries et al., 2004; Oosterom et al., 2015). A temporary delay in early postnatal cerebellar development was reported in newborn mice injected intraperitoneally with low titers of CMV (Koontz et al., 2008). In our infected mice, we identified the cerebellum as a preferential site for viral localization in the brain. We examined cerebellar anatomy and histology in control and infected mice with or without VCD therapy. CMV infection of the developing brain resulted in the disruption of cerebellar development, with a $60 \%$ decrease in the total area of this region compared with uninfected controls $(F=8.56, p<0.001$ ANOVA; Fig. 10A,B). CMV-infected mice displayed a substantial loss of PCs and a thinner ML, which contains PC dendritic trees, parallel fibers of the granule cells, Bergmann glia radial processes, and basket and stellate cells (Fig. 10C-E). Reduced thickness of the cerebellar IGL was also found (Fig. 10F). PCs were not only decreased in number but also misplaced (Fig. 10G). In addition, the external granular layer (EGL), normally undetectable after P21 in rodent brains (Ferguson, 1996), could still be identified in CMV-infected untreated mice at P30, whereas no EGL was visible in controls (Fig. 10H). Alignment of PCs and maturation of their dendritic trees, as well as granule cell precursor proliferation and inward migration from the EGL to the IGL, occur during the first 3 postnatal weeks of life in rodents (Inouye and $\mathrm{Mu}-$ rakami, 1980; Ferguson, 1996). VCD treatment rescued the altered cerebellar development of infected animals, restoring normal cortical layer thickness and representation and markedly increasing PC number (Fig. 10C-H). These drugmediated positive effects ultimately resulted in normalization of cerebellar size (Fig. 10A,B). No adverse side effects on either brain growth or morphometric parameters were detected in uninfected controls receiving VCD compared with their vehicle-treated counterparts.

\section{Block of CMV infection in human fetal brain cells}

Mouse and human forms of CMV share a close similarity in their viral genomes, but each retains species specificity (Rawlinson et al., 1996; Mocarski et al., 2007). In the experiments above, we used mCMV in mice. Here, to corroborate that the results we found above in our in vivo model with mCMV generalize to hCMV, we examined the actions of VCD on hCMV-infected human fetal astrocytes, a common cellular 

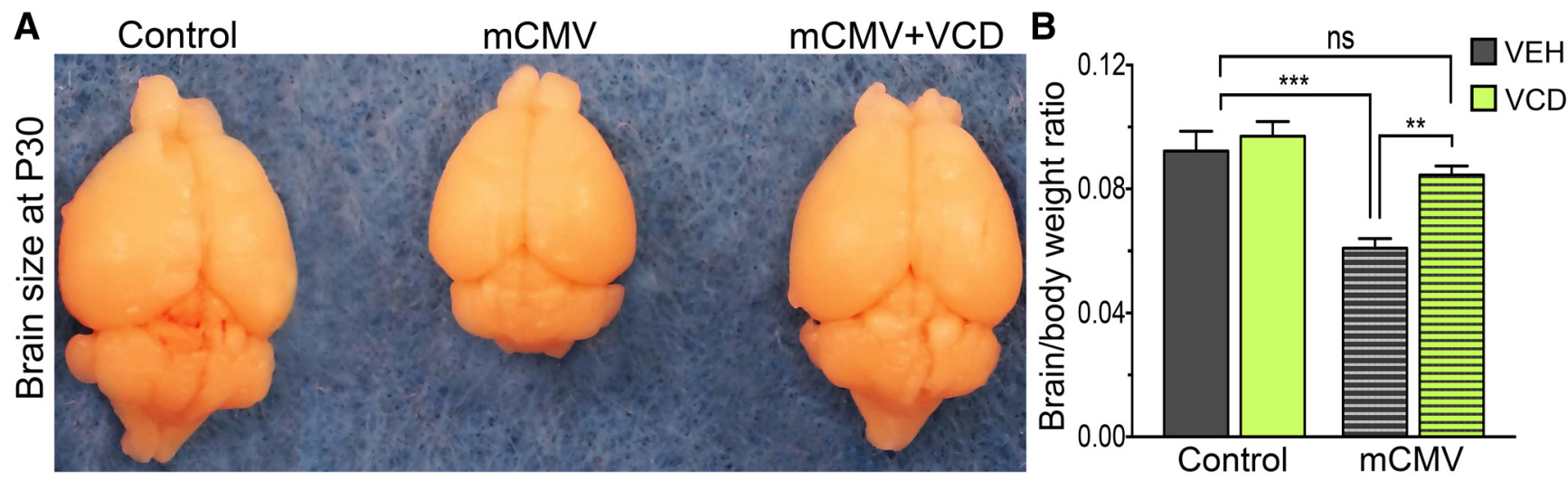

Figure 9. Valnoctamide reverses deficient brain growth induced by mCMV infection. $A$, Photograph shows decreased brain size in an infected, untreated mouse (i.e., mCMV; middle) compared with an uninfected control (left). VCD treatment restores normal brain growth (mCMV+VCD, right). Quantification of VCD-mediated benefits on postnatal brain growth by calculation of brain-to-body weight ratio. Values are reported as the mean $\pm \mathrm{SEM} ; n=10$ mice/group (3 litters). ns, Not significant. ${ }^{* *} p<0.01,{ }^{* * *} p<0.001 ;$ one-way ANOVA with Bonferroni's post hoc test $(\boldsymbol{B})$.

target that can play an important role in virus dispersal in the brain (Lokensgard et al., 1999; van den Pol et al., 1999). VCD substantially decreased hCMV infectivity of human fetal astrocytes as assessed by quantification of cells expressing the CMVGFP-reporter (Fig. 11A). Viral replication was also diminished in the presence of the drug, with a reduction in viral titer by $\sim 100$ fold $\left(4.92 \times 10^{5} \pm 5.84 \times 10^{4} \mathrm{pfu} / \mathrm{ml}\right.$ in vehicle-treated cultures vs $6.31 \times 10^{3} \pm 3.06 \times 10^{3} \mathrm{pfu} / \mathrm{ml}$ in VCD-treated cultures; $p<$ 0.0001, Mann-Whitney $U$ test; Fig. 11B).

VCD appears to act at an early stage of hCMV infection in fibroblasts and has no antiviral effect on the unrelated vesicular stomatitis virus (Ornaghi et al., 2016). To determine which step of the hCMV replication cycle was inhibited by VCD in human fetal astrocytes, we used a series of experiments to assess virus attachment to the cellular surface and penetration into the cytoplasmic space. This was accomplished by shifting the incubation temperature from $4^{\circ} \mathrm{C}$ (which allows virus attachment but not fusion and internalization) to $37^{\circ} \mathrm{C}$ (which allows virus fusion and internalization; Mocarski et al., 2007; Chan and Yurochko, 2014). Viral genome quantification by qRT-PCR showed that VCD appeared to block hCMV attachment to fetal astrocytes (Fig. 11C). In the presence of VCD, the amount of virus bound to the cell surface was decreased by $60 \%$ compared with control cultures not treated with VCD ( $p=0.0007$, unpaired Student's $t$ test). VCD did not appear to block hCMV fusion/internalization in the astrocytes. This also corroborates that the mechanism of VCD block of CMV occurs at an early stage of infection and appears unrelated to the genomic mechanisms of other approved anti-CMV compounds.

\section{Discussion}

Our data show that low-dose VCD administered outside the brain during early development effectively suppresses CMV inside the brain of infected mice via two different sites of action. One is that VCD reduces peripheral levels of CMV, thereby decreasing the amount of virus available for entry into the brain. A second is that VCD acts directly within the brain to block existing brain CMV infection. These results are consistent with anti-CMV activity of VCD outside the brain (Ornaghi et al., 2016). Importantly, the antiviral action of VCD begins shortly after administration and effectively attenuates CMV levels throughout the brain during the critical period of postnatal brain development.
This decrease in viral load is accompanied by a concomitant restoration of normal early neurological outcomes in infected neonatal mice treated with VCD. Late-onset neurobehavioral dysfunction, including motor impairment and social and exploratory behavior disturbances, as well as virally induced deficient brain growth and disrupted cerebellar development, are substantially attenuated in CMV-infected adolescent mice, which received VCD during the neonatal period, suggesting long-lasting beneficial effects. We detected no adverse collateral effects on the neurodevelopment of uninfected control mice treated with VCD.

An important underlying rationale of our study is that the newborn mouse brain is substantially less developed than the newborn human brain. Based on the timing of the brain growth spurt, initial neurogenesis, establishment and refinement of connections, myelination, and gliogenesis, the mouse CNS at birth is proposed to parallel the early second-trimester human fetal CNS (Clancy et al., 2001, 2007a,b; Branchi et al., 2003; Workman et al., 2013). This is a critical period for human brain development and for hCMV infection (Manicklal et al., 2013). By infecting mouse pups on the day of birth, this animal model provides an informative means to study the effects of CMV on the developing brain. Infected newborn mice display similar brain pathology and neurological symptoms to that reported in congenitally infected human infants, including microcephaly, cerebellar hypoplasia, neuronal loss, neurodevelopmental delays, motor impairments, and behavioral disturbances (Perlman and Argyle, 1992; de Vries et al., 2004; Pass et al., 2006; Lipitz et al., 2013; Kimberlin et al., 2015; De Kegel et al., 2016; James and Kimberlin, 2016). These data support the validity of this in vivo model for investigating CMV infection and novel anti-CMV treatments during early brain development.

Despite being partially effective, currently available CMV antiviral agents, including ganciclovir and its prodrug valganciclovir, foscarnet, cidofovir, and fomivirsen, display both toxic and teratogenic actions (Mercorelli et al., 2011; James and Kimberlin, 2016). For this reason, they are not approved or recommended for the treatment of pregnant women or infected fetuses or neonates, thus depriving those who may need it the most, or at best delaying treatment and hindering potential prevention or amelioration of CMV-induced brain defects during early development (Kimberlin et al., 2015). Because less severely infected human infants are also at risk for late-onset neurological compli- 
A

A Control
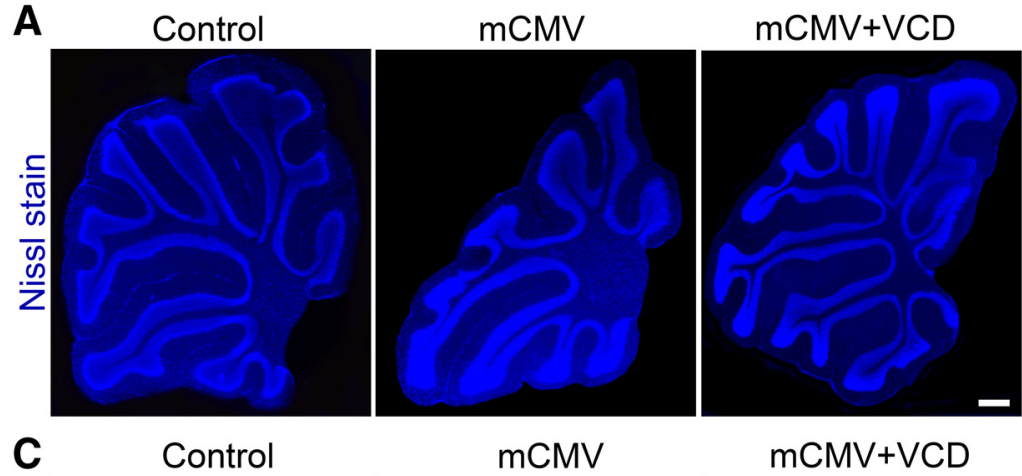

mCMV

$\mathrm{mCMV}+\mathrm{VCD}$
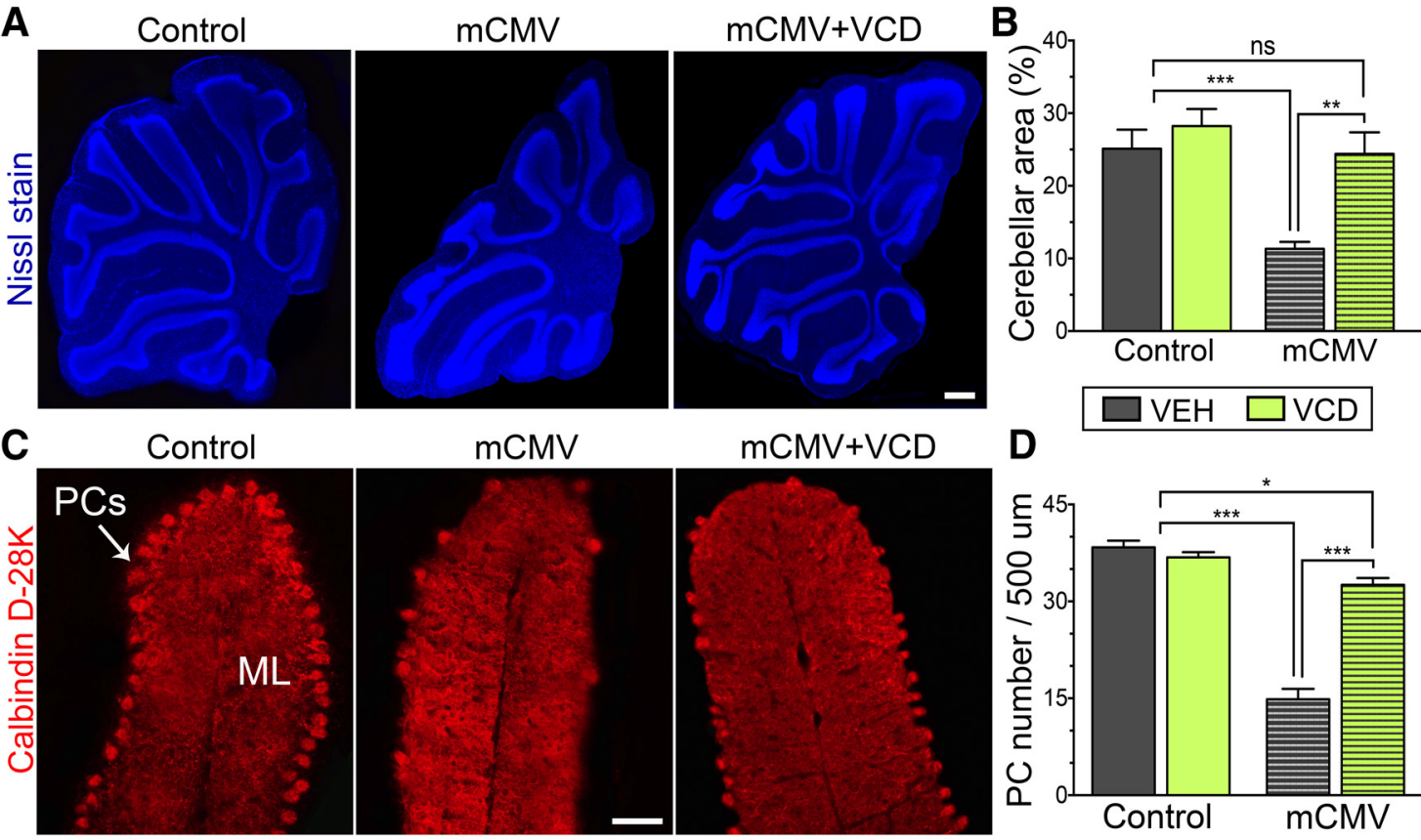

E
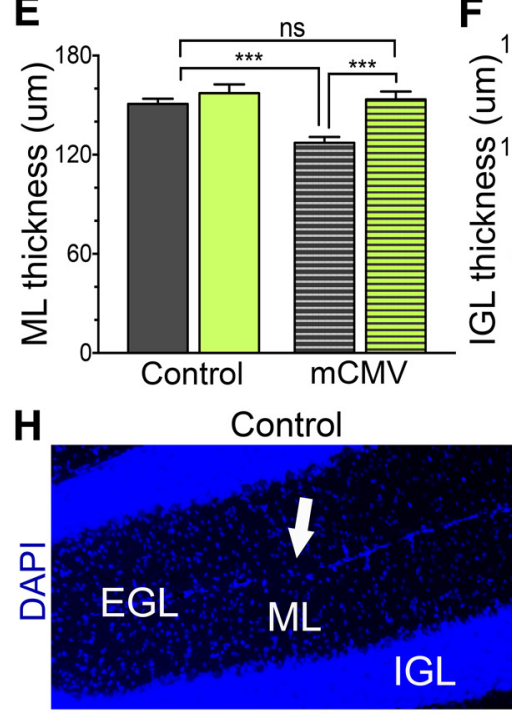

$\mathbf{F}$

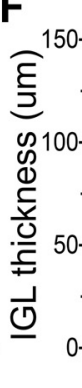

G

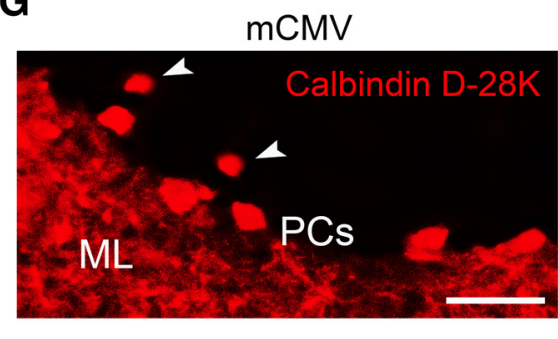

Control

ns
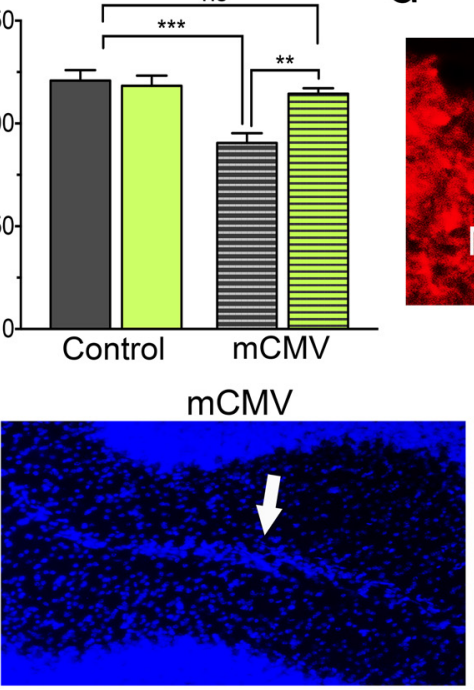

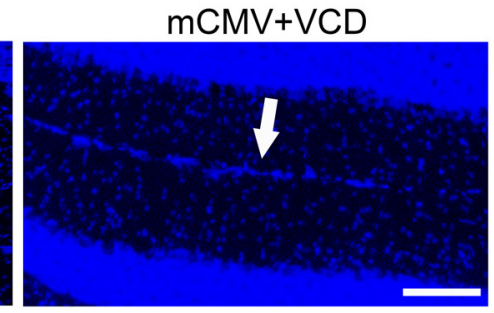

Figure 10. Valnoctamide substantially ameliorates cerebellar development in $\mathrm{mCMV}$-infected mice. $\boldsymbol{A}$, Photomicrograph of representative fluorescent Nissl-stained cerebellar areas in control (left) and infected mice with (right, $\mathrm{mCMV}+\mathrm{VCD}$ ) or without (middle, $\mathrm{mCMV}$ ) VCD. Note the delayed foliation in infected, untreated cerebellum, rescued by VCD. Scale bar, $200 \mu \mathrm{m}$. $\boldsymbol{B}$, Graph depicts cerebellar area, expressed as a percentage of total brain area (three sagittal sections/animal, five animals/group). C, Photomicrograph showing cerebellar PCs and ML by means of calbindin D-28K staining. Infected, untreated cerebellum (middle) displays loss of PCs and thinner ML compared with uninfected control (left); VCD improves both parameters (right). Scale bar, $200 \mu \mathrm{m}$. $\boldsymbol{D}-\boldsymbol{F}$, Quantification of $\mathrm{PC}$ number $(\boldsymbol{D})$, and ML $(\boldsymbol{E})$ and IGL thickness $(\boldsymbol{F})$ along $500 \mu \mathrm{m}$ of the primary fissure (prf; both sides; three sagittal sections/mouse, five mice/group). $\boldsymbol{G}$, Fluorescent micrograph of heterotopic PCs (arrowheads) identified in an infected untreated cerebellum. Scale bar, $100 \mu \mathrm{m}$. $\boldsymbol{H}$, Photomicrograph displays pathological persistence of EGL in $\mathrm{mCMV}$-infected, untreated cerebellum at P30 (middle); no EGL could be identified at the same time point in uninfected control (left) and infected, VCD-treated cerebellum (right). Scale bar, $200 \mu \mathrm{m}$. Values are reported as the mean \pm SEM. ns, Not significant. ${ }^{*} p<0.05,{ }^{* *} p<0.01,{ }^{* * *} p<0.001$; one-way ANOVA with Bonferroni's post hoc test.

cations including cognitive and motor disabilities, behavioral disturbances, visual deficits, and hearing impairment (James and Kimberlin, 2016), the development of anti-CMV compounds with safer in vivo profiles that can be used in all infected neonates would be of substantive benefit.

VCD has shown no teratogenic or toxic activity in several studies using different animal models of early development (Radatz et al., 1998; Shekh-Ahmad et al., 2014; Mawasi et al., 2015; Wlodarczyk et al., 2015) and has been safely used for many years to treat neuropsychiatric disorders in adults (Stepansky, 1960;
Goldberg, 1961; Harl, 1964). Further confirmation of its safety profile has derived from preclinical and clinical investigations of drug-mediated anti-convulsant and mood-stabilizing actions (Barel et al., 1997; Lindekens et al., 2000; Isoherranen et al., 2003; Winkler et al., 2005; Bersudsky et al., 2010; Kaufmann et al., 2010; Mareš et al., 2013; Shekh-Ahmad et al., 2015; Bialer et al., 2017; Modi et al., 2017). VCD is effective at a low-micromolar dose level, a slightly reduced level of efficacy compared with ganciclovir (Ornaghi et al., 2016); nonetheless, we found substantial CMV inhibition in vivo with subcutaneous delivery. We 

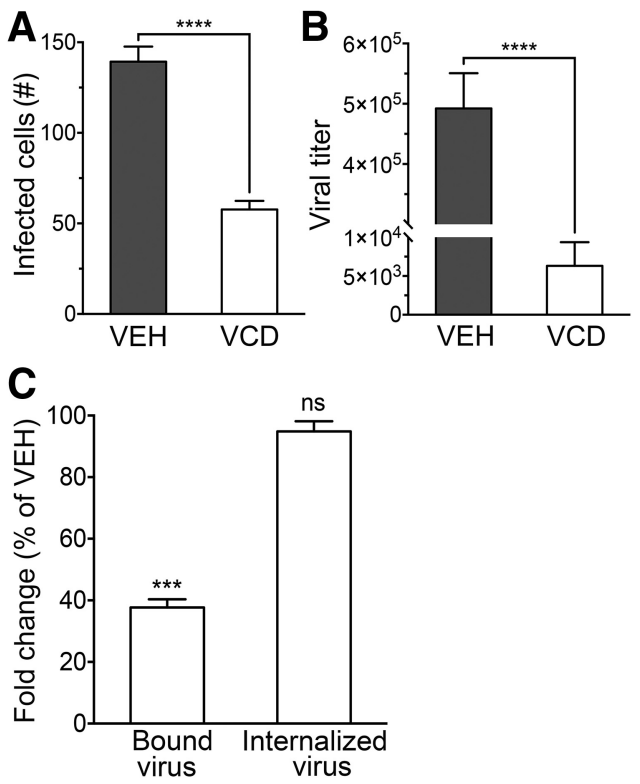

Figure 11. Valnoctamide suppresses hCMV infectivity and replication in human fetal astrocytes by blocking virus attachment to the cell. $A, B$, Human fetal astrocyte cells were pretreated (for $1 \mathrm{~h}$ ) with VCD $(100 \mu \mathrm{M})$ or vehicle (VEH) before inoculation with hCMV using an MOl of 0.1 . VCD treatment decreased hCMV infectivity and replication as assessed by GFP-positive cell counting $(\boldsymbol{A})$ and viral yield assay $(\boldsymbol{B})$ at $48 \mathrm{hpi}$. $\boldsymbol{C}$, Virus-inoculated human fetal astrocytes were exposed to VCD or vehicle $(100 \mu \mathrm{m})$ for $1 \mathrm{~h}$ at either $4^{\circ} \mathrm{C}$ or $37^{\circ} \mathrm{C}$ to assess hCMV attachment to ("bound virus") and internalization into ("internalized virus") the cell. Viral DNA was quantified by qRT-PCR and results expressed as the percentage of control (vehicle-treated cultures considered as 100\%). Graphs represent the average of three separate experiments each performed in triplicate; error bars correspond to SE. ns, Not significant. ${ }^{* * *} p<0.001,{ }^{* * * *} p<0.0001$, unpaired Student's $t$ test in $\boldsymbol{A}$ and C, Mann-Whitney $U$ test in $\boldsymbol{B}$; in $\boldsymbol{C}$, significance refers to the comparison between VCDand vehicle-treated cultures in each assay.

focused on newborn mice and identified potent anti-CMV actions of VCD; further studies focusing on VCD anti-CMV efficacy in fetal development and on the inhibition of transplacental transmission leading to brain infection will be beneficial.

The species specificity of CMV replication prevents testing the activity of novel antiviral agents on hCMV in animal models (Mocarski et al., 2007). Murine and human CMV share similar genomes, and anti-CMV drugs effective against mCMV are likely to also be active against hCMV (Rawlinson et al., 1996). The attenuation of hCMV infection of human fetal astrocytes by VCD corroborates the utility of our in vivo mouse model and suggests that VCD should also be effective against hCMV in the developing and adult human brain. In addition, VCD appears to act by blocking hCMV attachment to the cell membrane as described here in fetal astrocytes and previously in non-brain cells (Ornaghi et al., 2016), a mechanism of action that is different from that of currently available hCMV antiviral agents (Mercorelli et al., 2011). This also suggests the potential of VCD as a therapeutic option in immunocompromised adults, for whom the emergence of drug-resistant CMV strains has become a substantial challenge. Combination therapies, which can include two or more antiviral compounds, may help in controlling this problem, but are limited by drug-related toxicity and CMV cross-resistance to currently approved antiviral agents (Drew, 2000; James and Prichard, 2011). By displaying a good safety profile and a novel mechanism of anti-CMV activity, VCD may represent a valid therapeutic choice for effective and safe combination treatments potentially meriting testing in immunocompromised individuals. Other closely related molecules, for instance, valpromide, may also attenuate CMV (Ornaghi et al., 2016), but because valpromide can be metabolized to valproate, which can enhance virus infections, VCD is a better alternative due to the absence of conversion to valproate (Bialer et al., 1990; Bialer, 1991). That both related compounds show anti-CMV properties suggests that other structurally related compounds may also possess antiviral potential. These compounds have not previously been recognized as possessing anti-CMV actions; because both valpromide and VCD not only have similar antiepileptic actions and sedative properties in psychiatric patients, but also block CMV infections, this raises the possibility that the neurotropic and antiviral mechanisms of action may not be unrelated.

The dose of VCD we use here, with a $6 \mathrm{~g}$ developing mouse body weight, is $5 \mathrm{mg} / \mathrm{kg}$. This amount is similar to or less than the dose of existing compounds used to treat CMV in clinical settings; for instance, assuming a $60 \mathrm{~kg}$ body weight, ganciclovir can be used from 5 up to $20 \mathrm{mg} / \mathrm{kg} / \mathrm{d}$ in patients with serious infections (Kotton et al., 2013; Choopong et al., 2016; Genentech USA, 2016). Furthermore, the $5 \mathrm{mg} / \mathrm{kg}$ dose of VCD for treating CMV infection is lower than the dose used to attenuate seizures and neuropathic pain in neonatal and adult rodent experiments (Winkler et al., 2005; Kaufmann et al., 2010; Mareš et al., 2013; Shekh-Ahmad et al., 2014) and is less than the $20 \mathrm{mg} / \mathrm{kg}$ dose that can be used in humans to treat psychiatric dysfunction (Stepansky, 1960; Goldberg, 1961; Harl, 1964; Bersudsky et al., 2010). Together, these findings suggest that VCD may be able to attenuate CMV in the human brain at doses that should be both effective and tolerable.

CMV has been detected in a substantial number of brain tumors and has been postulated to play a role in the initiation or progression of malignant gliomas (Cobbs et al., 2007; Odeberg et al., 2007; Mitchell et al., 2008; Knight et al., 2013), although the possibility remains that CMV has a greater affinity for existing glial-type cells than for normal brain cells (van den Pol et al., 1999) rather than a causative role in oncogenesis. Although further substantiation is merited (Lau et al., 2005), if CMV does play a role in the enhancement of brain tumor growth, the use of VCD to attenuate CNS CMV may prove beneficial in attenuating tumor progression.

In conclusion, our study shows that subcutaneous low-dose VCD effectively and safely attenuates mCMV replication in the developing mouse brain and rescues these animals from virally induced brain defects and adverse neurological outcomes. We also show that VCD suppresses hCMV replication in human fetal brain cells by blocking viral attachment to the cell surface. Considering that VCD is already clinically available, has proven to be safe in multiple models of early development, and displays a novel mechanism of anti-CMV action, it merits further clinical testing for possible therapeutic utility in the treatment of CMV in the mature and developing human brain.

\section{References}

American Psychiatric Association (2013) Diagnostic and statistical manual of mental disorders (5th ed.). Arlington, VA: American Psychiatric Publishing.

Barel S, Yagen B, Schurig V, Soback S, Pisani F, Perucca E, Bialer M (1997) Stereoselective pharmacokinetic analysis of valnoctamide in healthy subjects and in patients with epilepsy. Clin Pharmacol Ther 61:442-449. CrossRef Medline

Bersudsky Y, Applebaum J, Gaiduk Y, Sharony L, Mishory A, Podberezsky A, Agam G, Belmaker RH (2010) Valnoctamide as a valproate substitute 
with low teratogenic potential in mania: a double-blind, controlled, add-on clinical trial. Bipolar Disord 12:376-382. CrossRef Medline

Bialer M (1991) Clinical pharmacology of valpromide. Clin Pharmacokinet 20:114-122. CrossRef Medline

Bialer M, Haj-Yehia A, Barzaghi N, Pisani F, Perucca E (1990) Pharmacokinetics of a valpromide isomer, valnoctamide, in healthy subjects. Eur J Clin Pharmacol 38:289-291. CrossRef Medline

Bialer M, Johannessen SI, Levy RH, Perucca E, Tomson T, White HS (2017) Progress report on new antiepileptic drugs: a summary of the Thirteenth Eilat Conference on New Antiepileptic Drugs and Devices (EILAT XIII). Epilepsia 58:181-221. CrossRef Medline

Branchi I, Bichler Z, Berger-Sweeney J, Ricceri L (2003) Animal models of mental retardation: from gene to cognitive function. Neurosci Biobehav Rev 27:141-153. CrossRef Medline

Brooks SP, Dunnett SB (2009) Tests to assess motor phenotype in mice: a user's guide. Nat Rev Neurosci 10:519-529. CrossRef Medline

Butler D (2016) Zika raises profile of more common birth-defect virus. Nature 535:17. CrossRef Medline

Calamandrei G, Venerosi A, Branchi I, Chiarotti F, Verdina A, Bucci F, Alleva E (1999) Effects of prenatal AZT on mouse neurobehavioral development and passive avoidance learning. Neurotoxicol Teratol 21:29-40. CrossRef Medline

Cannon MJ, Davis KF (2005) Washing our hands of the congenital cytomegalovirus disease epidemic. BMC Public Health 5:70. CrossRef Medline

Carter RJ, Morton J, Dunnett SB (2001) Motor coordination and balance in rodents. Curr Protoc Neurosci Chapter 8:Unit 8.12. CrossRef Medline

Chan GC, Yurochko AD (2014) Analysis of cytomegalovirus binding/entrymediated events. Methods Mol Biol 1119:113-121. CrossRef Medline

Cheeran MC, Lokensgard JR, Schleiss MR (2009) Neuropathogenesis of congenital cytomegalovirus infection: disease mechanisms and prospects for intervention. Clin Microbiol Rev 22:99-126, Table of Contents. CrossRef Medline

Choopong P, Vivittaworn K, Konlakij D, Thoongsuwan S, Pituksung A, Tesavibul N (2016) Treatment outcomes of reduced-dose intravitreal ganciclovir for cytomegalovirus retinitis. BMC Infect Dis 16:164. CrossRef Medline

Clancy B, Darlington RB, Finlay BL (2001) Translating developmental time across mammalian species. Neuroscience 105:7-17. CrossRef Medline

Clancy B, Finlay BL, Darlington RB, Anand KJ (2007a) Extrapolating brain development from experimental species to humans. Neurotoxicology 28: 931-937. CrossRef Medline

Clancy B, Kersh B, Hyde J, Darlington RB, Anand KJ, Finlay BL (2007b) Web-based method for translating neurodevelopment from laboratory species to humans. Neuroinformatics 5:79-94. CrossRef Medline

Cobbs CS, Soroceanu L, Denham S, Zhang W, Britt WJ, Pieper R, Kraus MH (2007) Human cytomegalovirus induces cellular tyrosine kinase signaling and promotes glioma cell invasiveness. J Neurooncol 85:271-280. CrossRef Medline

Crawley JN (2007) Mouse behavioral assays relevant to the symptoms of autism. Brain Pathol 17:448-459. CrossRef Medline

De Kegel A, Maes L, Dhooge I, van Hoecke H, De Leenheer E, Van Waelvelde H (2016) Early motor development of children with a congenital cytomegalovirus infection. Res Dev Disabil 48:253-261. CrossRef Medline

de Vries LS, Gunardi H, Barth PG, Bok LA, Verboon-Maciolek MA, Groenendaal F (2004) The spectrum of cranial ultrasound and magnetic resonance imaging abnormalities in congenital cytomegalovirus infection. Neuropediatrics 35:113-119. CrossRef Medline

Dollard SC, Grosse SD, Ross DS (2007) New estimates of the prevalence of neurological and sensory sequelae and mortality associated with congenital cytomegalovirus infection. Rev Med Virol 17:355-363. CrossRef Medline

Drew WL (2000) Ganciclovir resistance: a matter of time and titre. Lancet 356:609-610. CrossRef Medline

Ferguson SA (1996) Neuroanatomical and functional alterations resulting from early postnatal cerebellar insults in rodents. Pharmacol Biochem Behav 55:663-671. CrossRef Medline

Fleming SM, Salcedo J, Fernagut PO, Rockenstein E, Masliah E, Levine MS, Chesselet MF (2004) Early and progressive sensorimotor anomalies in mice overexpressing wild-type human $\alpha$-synuclein. J Neurosci 24:94349440. CrossRef Medline

Fleming SM, Ekhator OR, Ghisays V (2013) Assessment of sensorimotor function in mouse models of Parkinson's disease. J Vis Exp (76):e50303. CrossRef Medline

Fox WM (1965) Reflex-ontogeny and behavioural development of the mouse. Anim Behav 13:234-241. CrossRef Medline

Fukui Y, Shindoh K, Yamamoto Y, Koyano S, Kosugi I, Yamaguchi T, Kurane I, Inoue N (2008) Establishment of a cell-based assay for screening of compounds inhibiting very early events in the cytomegalovirus replication cycle and characterization of a compound identified using the assay. Antimicrob Agents Chemother 52:2420-2427. CrossRef Medline

Gandhi MK, Khanna R (2004) Human cytomegalovirus: clinical aspects, immune regulation, and emerging treatments. Lancet Infect Dis 4:725738. CrossRef Medline

Garofoli F, Lombardi G, Orcesi S, Pisoni C, Mazzucchelli I, Angelini M, Balottin U, Stronati M (2017) An Italian prospective experience on the association between congenital cytomegalovirus infection and autistic spectrum disorder. J Autism Dev Disord 47:1490-1495. CrossRef Medline

Gault E, Michel Y, Dehée A, Belabani C, Nicolas JC, Garbarg-Chenon A (2001) Quantification of human cytomegalovirus DNA by real-time PCR. J Clin Microbiol 39:772-775. CrossRef Medline

Genentech USA (2016) Cytovene (ganciclovir sodium), prescribing information. South San Francisco, CA: Genentech USA.

Goldberg M (1961) Effects of a new tranquilizer, valmethamide, in psychiatric outpatient care. Dis Nerv Syst 22:346-348. Medline

Guyenet SJ, Furrer SA, Damian VM, Baughan TD, La Spada AR, Garden GA (2010) A simple composite phenotype scoring system for evaluating mouse models of cerebellar ataxia. J Vis Exp (39):e1787. CrossRef Medline

Harl FM (1964) Clinical study of valnoctamide on 70 neuropsychiatric clinic patients undergoing ambulatory treatment. Presse Med 72:753754. Medline

Inouye M, Murakami U (1980) Temporal and spatial patterns of Purkinje cell formation in the mouse cerebellum. J Comp Neurol 194:499-503. CrossRef Medline

Isoherranen N, White HS, Klein BD, Roeder M, Woodhead JH, Schurig V, Yagen B, Bialer M (2003) Pharmacokinetic-pharmacodynamic relationships of $(2 \mathrm{~S}, 3 \mathrm{~S})$-valnoctamide and its stereoisomer $(2 \mathrm{R}, 3 \mathrm{~S})$-valnoctamide in rodent models of epilepsy. Pharm Res 20:1293-1301. CrossRef Medline

James SH, Kimberlin DW (2016) Advances in the prevention and treatment of congenital cytomegalovirus infection. Curr Opin Pediatr 28:81-85. CrossRef Medline

James SH, Prichard MN (2011) The genetic basis of human cytomegalovirus resistance and current trends in antiviral resistance analysis. Infect Disord Drug Targets 11:504-513. CrossRef Medline

Jarvis MA, Wang CE, Meyers HL, Smith PP, Corless CL, Henderson GJ, Vieira J, Britt WJ, Nelson JA (1999) Human cytomegalovirus infection of caco- 2 cells occurs at the basolateral membrane and is differentiation state dependent. J Virol 73:4552-4560. Medline

Kaufmann D, Yagen B, Minert A, Wlodarczyk B, Finnell RH, Schurig V, Devor M, Bialer M (2010) Evaluation of the antiallodynic, teratogenic and pharmacokinetic profile of stereoisomers of valnoctamide, an amide derivative of a chiral isomer of valproic acid. Neuropharmacology 58: 1228-1236. CrossRef Medline

Kenneson A, Cannon MJ (2007) Review and meta-analysis of the epidemiology of congenital cytomegalovirus (CMV) infection. Rev Med Virol 17:253-276. CrossRef Medline

Kimberlin DW, Jester PM, Sánchez PJ, Ahmed A, Arav-Boger R, Michaels MG, Ashouri N, Englund JA, Estrada B, Jacobs RF, Romero JR, Sood SK, Whitworth MS, Abzug MJ, Caserta MT, Fowler S, Lujan-Zilbermann J, Storch GA, DeBiasi RL, Han JY, et al (2015) Valganciclovir for symptomatic congenital cytomegalovirus disease. N Engl J Med 372:933-943. CrossRef Medline

Knight A, Arnouk H, Britt W, Gillespie GY, Cloud GA, Harkins L, Su Y, Lowdell MW, Lamb LS (2013) CMV-independent lysis of glioblastoma by ex vivo expanded/activated Vdelta1+ gammadelta T cells. PLoS One 8:e68729. CrossRef Medline

Koontz T, Bralic M, Tomac J, Pernjak-Pugel E, Bantug G, Jonjic S, Britt WJ (2008) Altered development of the brain after focal herpesvirus infection of the central nervous system. J Exp Med 205:423-435. CrossRef Medline

Kosmac K, Bantug GR, Pugel EP, Cekinovic D, Jonjic S, Britt WJ (2013) Glucocorticoid treatment of MCMV infected newborn mice attenuates 
CNS inflammation and limits deficits in cerebellar development. PLoS Pathog 9:e1003200. CrossRef Medline

Kotton CN, Kumar D, Caliendo AM, Asberg A, Chou S, Danziger-Isakov L, Humar A (2013) Updated international consensus guidelines on the management of cytomegalovirus in solid-organ transplantation. Transplantation 96:333-360. CrossRef Medline

Lau SK, Chen YY, Chen WG, Diamond DJ, Mamelak AN, Zaia JA, Weiss LM (2005) Lack of association of cytomegalovirus with human brain tumors. Mod Pathol 18:838-843. CrossRef Medline

Lindekens H, Smolders I, Khan GM, Bialer M, Ebinger G, Michotte Y (2000) In vivo study of the effect of valpromide and valnoctamide in the pilocarpine rat model of focal epilepsy. Pharm Res 17:1408-1413. CrossRef Medline

Lipitz S, Yinon Y, Malinger G, Yagel S, Levit L, Hoffman C, Rantzer R, Weisz B (2013) Risk of cytomegalovirus-associated sequelae in relation to time of infection and findings on prenatal imaging. Ultrasound Obstet Gynecol 41:508-514. CrossRef Medline

Lokensgard JR, Cheeran MC, Gekker G, Hu S, Chao CC, Peterson PK (1999) Human cytomegalovirus replication and modulation of apoptosis in astrocytes. J Hum Virol 2:91-101. Medline

Luong TN, Carlisle HJ, Southwell A, Patterson PH (2011) Assessment of motor balance and coordination in mice using the balance beam. J Vis Exp (49):e2376. CrossRef Medline

Manicklal S, Emery VC, Lazzarotto T, Boppana SB, Gupta RK (2013) The "silent" global burden of congenital cytomegalovirus. Clin Microbiol Rev 26:86-102. CrossRef Medline

Mareš P, Kubová H, Hen N, Yagen B, Bialer M (2013) Derivatives of valproic acid are active against pentetrazol-induced seizures in immature rats. Epilepsy Res 106:64-73. CrossRef Medline

Mawasi H, Shekh-Ahmad T, Finnell RH, Wlodarczyk BJ, Bialer M (2015) Pharmacodynamic and pharmacokinetic analysis of CNS-active constitutional isomers of valnoctamide and sec-butylpropylacetamide-amide derivatives of valproic acid. Epilepsy Behav 46:72-78. CrossRef Medline

Mercorelli B, Lembo D, Palù G, Loregian A (2011) Early inhibitors of human cytomegalovirus: state-of-art and therapeutic perspectives. Pharmacol Ther 131:309-329. CrossRef Medline

Mitchell DA, Xie W, Schmittling R, Learn C, Friedman A, McLendon RE, Sampson JH (2008) Sensitive detection of human cytomegalovirus in tumors and peripheral blood of patients diagnosed with glioblastoma. Neuro Oncol 10:10-18. CrossRef Medline

Mocarski, Shenk T, Pass RF (2007) Cytomegaloviruses. In: Fields virology (Fields BN, Knipe DM, Howley PM, eds), pp 2702-2751. Philadelphia: Lippincott, Williams \& Wilkins.

Modi HR, Ma K, Chang L, Chen M, Rapoport SI (2017) Valnoctamide, which reduces rat brain arachidonic acid turnover, is a potential nonteratogenic valproate substitute to treat bipolar disorder. Psychiatry Res 254:279-283. CrossRef Medline

Odeberg J, Wolmer N, Falci S, Westgren M, Sundtröm E, Seiger A, SöderbergNauclér C (2007) Late human cytomegalovirus (HCMV) proteins inhibit differentiation of human neural precursor cells into astrocytes. J Neurosci Res 85:583-593. CrossRef Medline

Ogawa N, Hirose Y, Ohara S, Ono T, Watanabe Y (1985) A simple quantitative bradykinesia test in MPTP-treated mice. Res Commun Chem Pathol Pharmacol 50:435-441. Medline

Oosterom N, Nijman J, Gunkel J, Wolfs TF, Groenendaal F, VerboonMaciolek MA, de Vries LS (2015) Neuro-imaging findings in infants with congenital cytomegalovirus infection: relation to trimester of infection. Neonatology 107:289-296. CrossRef Medline

Ornaghi S, Davis JN, Gorres KL, Miller G, Paidas MJ, van den Pol AN (2016) Mood stabilizers inhibit cytomegalovirus infection. Virology 499:121135. CrossRef Medline

Pass RF, Fowler KB, Boppana SB, Britt WJ, Stagno S (2006) Congenital cytomegalovirus infection following first trimester maternal infection: symptoms at birth and outcome. J Clin Virol 35:216-220. CrossRef Medline

Perlman JM, Argyle C (1992) Lethal cytomegalovirus infection in preterm infants: clinical, radiological, and neuropathological findings. Ann Neurol 31:64-68. CrossRef Medline

Pouliot W, Bialer M, Hen N, Shekh-Ahmad T, Kaufmann D, Yagen B, Ricks K, Roach B, Nelson C, Dudek FE (2013) A comparative electrographic analysis of the effect of sec-butyl-propylacetamide on pharmacoresistant status epilepticus. Neuroscience 231:145-156. CrossRef Medline
Radatz M, Ehlers K, Yagen B, Bialer M, Nau H (1998) Valnoctamide, valpromide and valnoctic acid are much less teratogenic in mice than valproic acid. Epilepsy Res 30:41-48. CrossRef Medline

Rawlinson WD, Farrell HE, Barrell BG (1996) Analysis of the complete DNA sequence of murine cytomegalovirus. J Virol 70:8833-8849. Medline

Rawlinson WD, Hamilton ST, van Zuylen WJ (2016) Update on treatment of cytomegalovirus infection in pregnancy and of the newborn with congenital cytomegalovirus. Curr Opin Infect Dis 29:615-624. CrossRef Medline

Reuter JD, Gomez DL, Wilson JH, Van Den Pol AN (2004) Systemic immune deficiency necessary for cytomegalovirus invasion of the mature brain. J Virol 78:1473-1487. CrossRef Medline

Sakamoto A, Moriuchi H, Matsuzaki J, Motoyama K, Moriuchi M (2015) Retrospective diagnosis of congenital cytomegalovirus infection in children with autism spectrum disorder but no other major neurologic deficit. Brain Dev 37:200-205. CrossRef Medline

Scattoni ML, Gandhy SU, Ricceri L, Crawley JN (2008) Unusual repertoire of vocalizations in the BTBR T+tf/J mouse model of autism. PLoS One 3:e3067. CrossRef Medline

Schneider T, Przewlocki R (2005) Behavioral alterations in rats prenatally exposed to valproic acid: animal model of autism. Neuropsychopharmacology 30:80-89. CrossRef Medline

Semple BD, Blomgren K, Gimlin K, Ferriero DM, Noble-Haeusslein LJ (2013) Brain development in rodents and humans: identifying benchmarks of maturation and vulnerability to injury across species. Prog Neurobiol 106-107:1-16. CrossRef Medline

Shekh-Ahmad T, Hen N, Yagen B, McDonough JH, Finnell RH, Wlodarczyk BJ, Bialer M (2014) Stereoselective anticonvulsant and pharmacokinetic analysis of valnoctamide, a CNS-active derivative of valproic acid with low teratogenic potential. Epilepsia 55:353-361. CrossRef Medline

Shekh-Ahmad T, Mawasi H, McDonough JH, Yagen B, Bialer M (2015) The potential of sec-butylpropylacetamide (SPD) and valnoctamide and their individual stereoisomers in status epilepticus. Epilepsy Behav 49:298302. CrossRef Medline

Shi L, Fatemi SH, Sidwell RW, Patterson PH (2003) Maternal influenza infection causes marked behavioral and pharmacological changes in the offspring. J Neurosci 23:297-302. Medline

Soerensen J, Jakupoglu C, Beck H, Förster H, Schmidt J, Schmahl W, Schweizer U, Conrad M, Brielmeier M (2008) The role of thioredoxin reductases in brain development. PLoS One 3:e1813. CrossRef Medline

Spampanato J, Dudek FE (2014) Valnoctamide enhances phasic inhibition: a potential target mechanism for the treatment of benzodiazepinerefractory status epilepticus. Epilepsia 55:e94-e98. CrossRef Medline

Stepansky W (1960) A clinical study in the use of valmethamide, an anxietyreducing drug. Curr Ther Res Clin Exp 2:144-147. Medline

St Omer VE, Ali SF, Holson RR, Duhart HM, Scalzo FM, Slikker W Jr (1991) Behavioral and neurochemical effects of prenatal methylenedioxymethamphetamine (MDMA) exposure in rats. Neurotoxicol Teratol 13:13-20. CrossRef Medline

Stubbs EG, Ash E, Williams CP (1984) Autism and congenital cytomegalovirus. J Autism Dev Disord 14:183-189. CrossRef Medline

Tanaka M, Machida Y, Niu S, Ikeda T, Jana NR, Doi H, Kurosawa M, Nekooki M, Nukina N (2004) Trehalose alleviates polyglutamine-mediated pathology in a mouse model of Huntington disease. Nat Med 10:148-154. CrossRef Medline

Tanaka T (1998) Effects of litter size on behavioral development in mice. Reprod Toxicol 12:613-617. CrossRef Medline

Tsutsui Y (2009) Effects of cytomegalovirus infection on embryogenesis and brain development. Congenit Anom (Kyoto) 49:47-55. CrossRef Medline

Turner KM, Lee HC, Boppana SB, Carlo WA, Randolph DA (2014) Incidence and impact of CMV infection in very low birth weight infants. Pediatrics 133:e609-e615. CrossRef Medline

van den Pol AN, Mocarski E, Saederup N, Vieira J, Meier TJ (1999) Cytomegalovirus cell tropism, replication, and gene transfer in brain. J Neurosci 19:10948-10965. Medline

van den Pol AN, Reuter JD, Santarelli JG (2002) Enhanced cytomegalovirus infection of developing brain independent of the adaptive immune system. J Virol 76:8842-8854. CrossRef Medline

van den Pol AN, Robek MD, Ghosh PK, Ozduman K, Bandi P, Whim MD, Wollmann G (2007) Cytomegalovirus induces interferon-stimulated 
gene expression and is attenuated by interferon in the developing brain. J Virol 81:332-348. CrossRef Medline

van den Pol AN, Mao G, Yang Y, Ornaghi S, Davis JN (2017) Zika virus targeting in the developing brain. J Neurosci 37:2161-2175. CrossRef Medline

Vieira J, Schall TJ, Corey L, Geballe AP (1998) Functional analysis of the human cytomegalovirus US28 gene by insertion mutagenesis with the green fluorescent protein gene. J Virol 72:8158-8165. Medline

Winkler I, Blotnik S, Shimshoni J, Yagen B, Devor M, Bialer M (2005) Efficacy of antiepileptic isomers of valproic acid and valpromide in a rat model of neuropathic pain. Br J Pharmacol 146:198-208. CrossRef Medline

Wlodarczyk BJ, Ogle K, Lin LY, Bialer M, Finnell RH (2015) Comparative teratogenicity analysis of valnoctamide, risperidone, and olanzapine in mice. Bipolar Disord 17:615-625. CrossRef Medline

Workman AD, Charvet CJ, Clancy B, Darlington RB, Finlay BL (2013) Modeling transformations of neurodevelopmental sequences across mammalian species. J Neurosci 33:7368-7383. CrossRef Medline

Yamashita Y, Fujimoto C, Nakajima E, Isagai T, Matsuishi T (2003) Possible association between congenital cytomegalovirus infection and autistic disorder. J Autism Dev Disord 33:455-459. CrossRef Medline

Yang M, Silverman JL, Crawley JN (2011) Automated three-chambered social approach task for mice. Curr Protoc Neurosci Chapter 8:Unit 8.26.

Zurbach KA, Moghbeli T, Snyder CM (2014) Resolving the titer of murine cytomegalovirus by plaque assay using the M2-10B4 cell line and a low viscosity overlay. Virol J 11:71. CrossRef Medline 